\title{
Organizational Psychology
} Review

\section{A Dynamic Reframing of the Social/Personal Identity Dichotomy}

\begin{tabular}{|c|l|}
\hline Journal: & Organizational Psychology Review \\
\hline Manuscript ID & OPR-20-0050.R2 \\
\hline Keywords: & $\begin{array}{l}\text { Self \& Identity, Intergroup relations, Cognition/Perception, Identity, } \\
\text { Identification, Social identity, Social/Personal identity, Social identity } \\
\text { theory, Organizational identification, Multiple identities }\end{array}$ \\
\hline Abstract: & $\begin{array}{l}\text { For decades, scholars in organizational and social psychology have } \\
\text { distinguished between two types of identity: social and personal. To } \\
\text { what extent, though, is this dichotomy useful for understanding } \\
\text { identities and their dynamics, and might a different approach facilitate } \\
\text { deeper insight? Such are the guiding questions of this article. I begin by } \\
\text { reviewing framings of the social/personal identity dichotomy in } \\
\text { organizational psychology, and tracing its origins and evolution in social } \\
\text { psychology. I then evaluate the strengths and limitations of this } \\
\text { dichotomy as a tool for understanding identities. In an attempt to retain } \\
\text { the dichotomy's strengths and overcome its limitations, I present a } \\
\text { modified conceptualization of the social and personal dimensions of } \\
\text { identity, one that defines these dimensions based on psychological } \\
\text { experience (not identity content), and treats them as two independent } \\
\text { continua (not two levels of a dichotomy, or opposing ends of a } \\
\text { continuum) that any given identity varies along across contexts. }\end{array}$ \\
\hline
\end{tabular}

\section{SCHOLARONE Manuscripts}




\title{
REFRAMING THE SOCIAL/PERSONAL IDENTITY DICHOTOMY
}

\begin{abstract}
For decades, scholars in organizational and social psychology have distinguished between two types of identity: social and personal. To what extent, though, is this dichotomy useful for understanding identities and their dynamics, and might a different approach facilitate deeper insight? Such are the guiding questions of this article. I begin by reviewing framings of the social/personal identity dichotomy in organizational psychology, and tracing its origins and evolution in social psychology. I then evaluate the strengths and limitations of this dichotomy as a tool for understanding identities. In an attempt to retain the dichotomy's strengths and overcome its limitations, I present a modified conceptualization of the social and personal dimensions of identity, one that defines these dimensions based on psychological experience (not identity content), and treats them as two independent continua (not two levels of a dichotomy, or opposing ends of a continuum) that any given identity varies along across contexts.
\end{abstract}

Keywords: identity; identification; social identity; personal identity; social/personal identity; social identity theory, self-categorization theory; optimal distinctiveness theory; work-related identity; organizational identification; organizational identity; work identity; professional identity; team identification; team identity; multiple identities 


\section{REFRAMING THE SOCIAL/PERSONAL IDENTITY DICHOTOMY}

\section{A Dynamic Reframing of the Social/Personal Identity Dichotomy}

Identities are central to human psychology. Recent decades have seen organizational scholars embrace this notion, leading to much research on the work-related influences on and consequences of identities, from a range of philosophical positions (for reviews, see Alvesson, Ashcraft, \& Thomas, 2008; Ashforth, Harrison, \& Corley, 2008; Brown, 2014; Caza, Vough, \& Puranik, 2018; Miscenko \& Day, 2016). Amongst those adopting a more realist ontology (Lincoln \& Guba, 1985), the notion that individuals have multiple identities comprising their overarching self-concept has garnered much empirical support, with research showcasing the plurality of people's identity sets, and the consequences of these various identities for individuals and organizations (e.g., Ramarajan, 2014; Ramarajan, Berger, \& Greenspan, 2017).

In recognizing that individuals have multiple identities, scholars have sought to classify these into meaningful categories, such as positive/negative (Dutton, Roberts, \& Bednar, 2010), work/non-work (Ramarajan \& Reid, 2013), and visible/invisible (Clair, Beatty, \& McLean, 2005). One particular approach to classifying identities has been especially prominent in organizational psychology: the social/personal identity dichotomy (SPID). Scholars typically invoke the SPID to distinguish between identities with external, "social" content on the one hand - such as groups, organizations, and social categories - and identities with internal, "personal" content on the other, such as traits, preferences, and attitudes (e.g., Ashforth \& Mael, 1989; Brown, 1997; Ibarra \& Barbulescu, 2010; Petriglieri, 2011). In social psychology, the SPID is also a conceptual cornerstone of social identity theory (Tajfel \& Turner, 1979) and self-categorization theory (Turner, Hogg, Oakes, Reicher, \& Wetherell 1987), both of which have significantly influenced understandings of identity within organizational psychology (e.g., Ashforth \& Mael, 1989; Hogg \& Terry, 2000). Indeed social identity theory has been invoked by organizational scholars to explain 


\section{REFRAMING THE SOCIAL/PERSONAL IDENTITY DICHOTOMY}

phenomena as diverse as work-related commitment (Meyer, Becker, \& van Dick, 2006), social entrepreneurship (Pan, Gruber, \& Binder, 2019), corporate mergers (Giessner, Ullrich, \& van Dick, 2011), stress (Steffens, Haslam, Schuh, Jetten, \& van Dick, 2017), and transitions to retirement (Froidevaux, Hirschi, \& Wang, 2018).

Given this centrality to much research, one would presume the parameters of the SPID (i.e., what exactly distinguishes social from personal identity) have been subject to much discussion amongst organizational scholars. Surprisingly, however, this issue remains largely unexplored (though see Ashforth, 2007). The institutionalization of the SPID also means that more critical questions about its utility as a tool for understanding the nature, dynamics, and consequences of identities are rarely raised. A notable exception in this regard is Vignoles's (2019) recent critique, which integrates a range of evidence to argue that most, if not all identities have both social and personal elements. Still, other important issues with the SPID remain uncovered, and importantly, the field is yet to consider the possibility of alternative, more theoretically fruitful ways of understanding the social and personal dimensions of identities.

Critically evaluating the SPID is worthwhile because certain underdeveloped areas of the identity literature within organizational psychology are potentially associated with its prevalence. Perhaps the most significant of these is the notion that theorizing on identity with a work focus, while often espousing the dynamic nature of identities, tends to portray them as fairly consistent in their psychological impact on individuals over time (Bednar, Galvin, Ashforth, \& Hafermalz, 2019; Miscenko \& Day, 2016). The SPID is by no means the only cause of this lack of dynamism, but is arguably a contributing factor: as I discuss in this article, the enduring framing of the SPID in organizational psychology portrays identities as inherently, exclusively, and permanently of one type or another, and therefore consistent in their impact on individuals over time. 


\section{REFRAMING THE SOCIAL/PERSONAL IDENTITY DICHOTOMY}

In addition, by dividing identities into two types, the framing of the SPID that predominates in organizational psychology forces scholars to decide what types are worthy of research attention — potentially at the expense of a more holistic, integrated understanding of identity writ large. Indeed organizational research to date has largely focused on the development and impact of social identities (Sluss \& Ashforth, 2007) — a concept embedded in the SPID - presumably because social identities are seen as more relevant to the types of outcomes typically prioritized in the field (i.e., those concerning the pursuit of collective or organizational goals). By contrast, less research has directly explored the dynamics and consequences of personal identities in organizations (though the wealth of organizational research on related phenomena such as personality, attitudes, and values indirectly touches on this issue), as well as those identities that do not cleanly fit in either category (e.g., identification with physical places or objects). This is a theoretically undesirable situation given that such identities have significant work-related consequences (e.g., Cable, Gino, \& Staats, 2013; Elsbach \& Flynn, 2013; Rogers, Corley, \& Ashforth, 2017).

In light of the SPID's potentially limiting influence on theorizing about identity, I have three aims in this article. First, to show that the typical framing of the SPID in organizational psychology over the past three decades, while aligned with how it was originally conceptualized in social identity theory (Turner, 1982), is misaligned with the more dynamic, experiential conceptualization of the SPID that emerged later in selfcategorization theory (Abrams, 1999, Simon, 1997; Turner et al., 1987). Second, I aim to evaluate the conceptual strengths and limitations of the SPID - in all its various framings. Third, I aim to overcome the limitations of the SPID uncovered through this evaluation, and ultimately facilitate deeper understanding of how individuals dynamically experience their identities, by presenting an alternative conceptualization of the social and personal dimensions of identity. 


\section{REFRAMING THE SOCIAL/PERSONAL IDENTITY DICHOTOMY}

Specifically, the approach I outline in this article does not assume that any given identity is inherently and/or permanently social or personal, as is common in framings of the SPID in organizational psychology. Instead, the approach assumes that all identities vary over time in the extent to which they are psychologically experienced socially (i.e., make an individual see themselves as part of a corresponding social entity) and personally (i.e., make an individual see themselves as an individual entity). While this approach shares an emphasis on dynamism and psychological experience with self-categorization theory (Simon, 1997; Turner et al., 1987), it diverges in that it conceptualizes the social and personal dimensions of identities as two independent continua, rather than two levels of a dichotomy, or opposing ends of a single continuum. As I will show, these two modifications enhance researchers' ability to capture the way people psychologically experience their identities within and beyond organizations, and also reveal new lines of inquiry for identity scholars.

For example, by acknowledging that the psychological experience of the same identity can vary across social situations, the approach facilitates exploration of the intrapersonal dynamics of identities in organizational contexts, something which others have recently highlighted as a priority for identity research in organizational psychology (e.g., Bednar et al., 2019; Miscenko \& Day, 2016). In addition, by treating the social and personal dimensions of identities as two continua, the approach encourages scholars to acknowledge that a single identity often has both socializing and individualizing consequences (Hornsey \& Jetten, 2004; Jetten \& Postmes, 2006), which raises new questions about identities that have to date been considered "social" (e.g., how and when might identities derived from organizations make individuals think and behave selfishly?) and "personal" (e.g., how might identities based on traits or preferences catalyze collective action in organizations?).

I organize this article according to each of my three aims noted above. First, I provide an overview of the typical framing of the SPID in organizational psychology and its origins 


\section{REFRAMING THE SOCIAL/PERSONAL IDENTITY DICHOTOMY}

and evolution in social psychology. I then evaluate the theoretical strengths and limitations of the SPID, and in light of this evaluation, make the case for a shift to a dynamic, twodimensional conceptualization of the social and personal dimensions of identity. I conclude by discussing implications of this reframing for theory and research on identity.

\section{Framings, Origins, and Evolution of the Social/Personal Identity Dichotomy}

In what follows, I present an overview of the SPID's typical framing in organizational psychology, its origins in social identity theory, and evolution in self-categorization theory. This historical exploration is important for three reasons. First, it shows that the static, content-based framing of the SPID that has endured in organizational psychology for decades, while consistent with the early framing of the SPID in social identity theory, is misaligned with the more dynamic, context-based framing that emerged later in selfcategorization theory. Second, as is not uncommon with seminal concepts and frameworks (e.g., Bridgman, Cummings, \& Ballard, 2019), the exploration shows that the SPID originated from a source to which it is not typically attributed. Finally, the review highlights that the SPID did not emerge to account for a consistent pattern of findings across a large number of studies. Rather, it was a hypothetical framework redeployed so often that it eventually became a taken-for-granted means of classifying identities. By exposing these origins, we begin to see the SPID not as the way of understanding the social and personal dimensions of identities, but rather one possibility.

\section{Content-Based Framing in Organizational Psychology}

Scholars have long been interested in the role of individual identities in organizational life (Albert, Ashforth, \& Dutton, 2000; Ashforth \& Mael, 1989; Ashforth et al., 2008). Researchers have explored identity from a variety of ontological and epistemological standpoints (Alvesson et al., 2008), and in relation to many "targets", such as organizations (Ashforth et al., 2008; Lee, Park, \& Khoo, 2015), work teams (Van Der Vegt \& Bunderson, 


\section{REFRAMING THE SOCIAL/PERSONAL IDENTITY DICHOTOMY}

2005), relationships (Sluss \& Ashforth, 2007, 2008), specific individuals (Ashforth, Schinoff, \& Rogers, 2016), and professions (Ibarra, 1999; Pratt, Rockmann, \& Kaufmann, 2006). The work-related consequences of identities have also been a popular focus, with scholars linking identity to outcomes such as organizational citizenship behavior (van Dick, Grojean, Christ, \& Wieseke, 2006), motivation (van Knippenberg, 2000), reactions to justice failure (Zhu, Martens, \& Aquino, 2012), creativity (Hirst, van Dick, \& van Knippenberg, 2009), and even employees' use of alcohol (Walker \& Bridgman, 2013).

In articles comprising this literature, researchers commonly introduce the SPID as an established way of categorizing the various identities that individuals hold. This tendency is noticeably common in articles published in the Academy of Management Review journal, a prominent outlet for theoretical work on identity in and around organizations. To illustrate this point, Table 1 lists the 19 articles published between 1989 and 2020 in the Academy of Management Review that 1) include either the term "identity" or "identification" (or the plurals "identities" or "identifications") in the title ( $n=74)$, and 2) make reference to the SPID (some implicitly, others explicitly).

What is clear from the excerpts in Table 1 is that scholars in organizational psychology typically frame the distinction between social and personal identities as a matter of identity content: identities are social if they have ostensibly extrinsic, "social" content (i.e., are based on social group or category membership) and personal if they have ostensibly intrinsic, "personal" content (i.e., are based on individual traits or characteristics). It is also notable that 5 of the sources in Table 1 (Ashforth, Schinoff, \& Brickson, 2020; Bolinger, Klotz, \& Leavitt, 2018; Cooper \& Thatcher, 2010; Piening, Salge, Antons, \& Kreiner, 2020; Sluss \& Ashforth, 2007) refer to a trichotomy rather than a dichotomy, distinguishing between personal (or individual), interpersonal (or relational), and social (or collective) 


\section{REFRAMING THE SOCIAL/PERSONAL IDENTITY DICHOTOMY}

identities. I elaborate the significance of these sources later when evaluating the strengths and limitations of the SPID.

Insert Table 1 here

I chose to begin the list of articles in Table 1 in 1989, as this was the year in which one of the most seminal articles on identity in organizational psychology was published Ashforth and Mael's (1989) "Social Identity Theory and the Organization." At the time of writing, Google Scholar has recorded over 13,000 citations of this article, easily making it the most cited work on identity published in a management or organization studies journal. As indicated by the title, Ashforth and Mael (1989) sought to incorporate social identity theory, which by 1989 was a well-established theory in social psychology, into theorizing about identity in organization studies. Of direct relevance to the current discussion, Ashforth and Mael state early on that:

"According to [social identity theory], the self-concept is comprised of a personal identity encompassing idiosyncratic characteristics (e.g., bodily attributes, abilities, psychological traits, interests) and a social identity encompassing salient group classifications.” (Ashforth \& Mael, 1989, p. 21, emphasis in original)

While brief, this statement seems to have had a lasting impact on understandings of the SPID within organizational psychology. Indeed, in examining subsequent framings of the SPID in Table 1, most closely reflect Ashforth and Mael's (1989) initial, content-based framing of the dichotomy. It is important to emphasize, though, that Ashforth and Mael (1989) were not claiming the SPID as their own creation, but instead introducing it to organizational psychology from the social identity approach ${ }^{1}$.

\section{Origins in Social Identity Theory}

\footnotetext{
${ }^{1}$ Following Hogg and Abrams (1988), I herein use the umbrella term "social identity approach" to refer jointly to social identity theory and self-categorization theory. Where I focus on just one of these more specific theories, I use the focal theory's name instead.
} 


\section{REFRAMING THE SOCIAL/PERSONAL IDENTITY DICHOTOMY}

Driven by a desire to better understand the social and psychological mechanisms of intergroup behavior, Henri Tajfel and colleagues developed social identity theory throughout the late 1960s and 1970s, (e.g., Tajfel, 1970, 1974 ; Tajfel, Billig, Bundy, \& Flament, 1971). In 1971, John Turner joined Tajfel's research programme as a doctoral student (Turner \& Reynolds, 2012), and would become a key figure in the social identity approach. Importantly for current purposes, Turner also appears to be the first social identity researcher to propose the SPID as a key conceptual element of the approach. In a 1982 chapter entitled "Towards a Cognitive Redefinition of the Social Group," Turner makes the following statement, which, given its centrality to the current discussion, I quote in full:

"We shall hypothesize that [social identity] represents one of the two major subsystems of the self-concept. Gergen (1971) distinguishes between the self-concept as a set of psychological processes and the self-concept as a cognitive structure. The latter he defines as 'the system of concepts available to a person in attempting to define himself' (1971, p. 23). He further reports that these concepts fall into two main classes (basing himself on Gordon's, 1968, research). Firstly, there are terms that denote one's membership of various formal and informal social groups, i.e., social categories such such as sex, nationality, political affiliation, religion and so on. Secondly, there are terms 'that are more personal in nature and that usually denote specific attributes of the individual' (p. 62) such as feelings of competence, bodily attributes, ways of relating to others, psychological characteristics, intellectual concerns, personal tastes and so on. It is evident that the first set of self-descriptions corresponds as a whole to our concept of social identity; the second set, similarly, we shall equate with and define as personal identity. Thus, social and personal identity are conceptualized as hypothetical, cognitive structures which together account for most of the self-concept." (Turner, 1982, p. 18)

This statement is pivotal for several reasons. First, based on my review of the social identity literature published before this chapter, it appears to be the first instance where social identity is explicitly juxtaposed with personal identity - an observation consistent with Turner's own comments on this chapter over two decades later (Turner, Reynolds, Haslam, \& Veenstra, 2006, p. 13).

Second, Turner's (1982) comment implies that social and personal identity are superordinate repositories ("sets") of more specific identities, and that determining the repository in which any given identity falls is a matter of content: those identities comprising 


\section{REFRAMING THE SOCIAL/PERSONAL IDENTITY DICHOTOMY}

one's broader social identity are based on self-perceived membership in social groups, categories, and so on, while identities comprising one's personal identity are based on individual traits, characteristics, and so on. We therefore see clear alignment between this statement and the content-based framing of the SPID that Ashforth and Mael (1989) later introduced to organizational psychology.

Turner's (1982) framing of social and personal identity as a dichotomy is also significant given that just four years earlier, Tajfel (1978, p. 41) dedicated several pages of a book chapter to outlining his view of intergroup and interindividual behavior as opposing ends of a continuum. Whilst acknowledging Tajfel's focus on behavior versus Turner's focus on identity, we see something of a conceptual misalignment here between these key figures in the social identity approach: Tajfel viewing behavior as more-or-less social or personal, and Turner viewing identities as either social or personal (as I show shortly, though, later work would see Turner reprise his mentor's notion of a continuum).

Finally, it is important to highlight that just as Ashforth and Mael (1989) introduced the SPID to organizational psychology from the social identity approach, so too did Turner (1982) introduce the SPID to the social identity approach from earlier work. Despite Gergen (1971) being the primary source Turner (1982) and some later researchers (Abrams, 1996; Hogg \& Abrams, 1988) drew on to validate the SPID, it is largely an extended summary of Gordon's (1968) more substantive treatment of the issue. In a relatively obscure chapter entitled "Self-Conceptions: Configurations of Content," Gordon (1968) reviews different approaches to categorizing the various elements of the self-concept, with a particular focus on how scholars can empirically capture the substantial variance in an individual's set of identities (or "self-conceptions," in Gordons's terms). In an early section of the chapter, Gordon proposes a two-pronged approach for classifying identities, which has clear parallels with the SPID as it is typically framed in organizational psychology to this day: 


\section{REFRAMING THE SOCIAL/PERSONAL IDENTITY DICHOTOMY}

"These considerations argue for a comprehensive view of self-conception. This must include both social identity represented by the combination of primarily noun-like social categories telling what the individual shares with others in those categories and the personal attributes that distinguish him from others." (Gordon, 1968, p. 119, emphasis in original)

Gordon (1968) draws on various sources in building up to this statement, but cites none in the statement itself. This lack of citations suggests Gordon believed he was introducing a novel approach for classifying identities. As with Turner's (1982) outline of the SPID, however, Gordon does not present the dichotomy as an empirically validated given, nor as a means for accounting for a large body of established findings. Rather, Gordon introduces the dichotomy more as a conceptual heuristic for structuring the various identities any one person can hold.

\section{Evolution in Self-Categorization Theory}

Despite its tentative framing, Turner's (1982) introduction of the SPID to social identity theory had a lasting impact, and would become a central assumption of selfcategorization theory. Turner developed self-categorization theory with various colleagues and doctoral students from the mid-1980s onwards, in an effort to better understand the precise psychological mechanisms involved in self-categorization, social identity, and intergroup behavior (e.g., Turner, 1985, Turner et al., 1987, Turner \& Reynolds, 2012). Conceptualizations of the SPID in self-categorization theory, however, changed substantially over the course of the theory's evolution.

Specifically, the late 1980s and 1990s saw proponents of self-categorization theory shift away from a content-based framing of the SPID, to a more dynamic, experiential, and context-sensitive view of social and personal identities (e.g., Abrams, 1996, 1999; Reicher, Spears, \& Postmes, 1995; Turner, Oakes, Haslam, \& McGarty, 1994). As part of this shift, social and personal identities came to be viewed more as dynamic psychological states, which individuals move between as they navigate different social contexts - a contrast to 


\section{REFRAMING THE SOCIAL/PERSONAL IDENTITY DICHOTOMY}

the earlier view in Turner (1982), which described them as stable "cognitive structures."

Abrams summarizes this shift in perspective as follows:

"Early writings on social identity (e.g., Turner and Giles, 1981; Hogg \& Abrams, 1988) described social and personal identity as broadly consisting of category memberships and traits, respectively. However, more recently (e.g., Abrams and Hogg, 1990a), particularly with the development of self-categorization theory (Turner et al., 1987), this view has been modified and developed; personal and social identities are representations of self at different levels of abstraction relative to both one another and the social frame of reference. Theoretically, only one self-image can be salient at any particular time. There is no requirement to specify the content of personal and social identifications, and indeed it is impossible to do so without knowledge of the subjective context (e.g. contrasting categories)." (Abrams, 1996, pp. 147-148)

Here we see social and personal identity described not as "cognitive structures" (Turner, 1982), but rather "representations of self at different levels of abstraction." Although still slightly vague phrasing, the implication seems to be that social and personal identity represent two lenses through which an individual construes and ultimately views themselves at any given moment (Simon, 1997). When social identity is salient (i.e., psychologically activated), an individual is thinking of themself as a member of whatever collective their social context has made salient (e.g., "we, the Germans"). When personal identity is salient, however, an individual is thinking of themself as an individual entity (e.g., "me, the German"). Indeed this view of social identity as a dynamic psychological state is at the core of the concept of "depersonalization" from self-categorization theory (Turner et al., 2006), which refers to an individual being in a psychological state where they "define and see themselves less as differing individual persons and more as the interchangeable representatives of some shared social category membership" (Turner et al., 1994, p. 455).

In addition to this change in how social and personal identities were conceptualized, the evolution of self-categorization theory also saw growing equivocality regarding the supposed dichotomous relationship between these two identities. For example, Abrams notes in the quote above that social and personal identities are necessarily mutually exclusive levels 


\section{REFRAMING THE SOCIAL/PERSONAL IDENTITY DICHOTOMY}

of abstraction, such that "only one self-image can be salient at any particular time." Yet over a decade earlier, John Turner, in something of a return to his mentor's perspective (Tajfel, 1978), describes them as opposing ends of a single continuum, stating that "social selfperception tends to vary along a continuum from the perception of self as a unique person...to the perception of self as an ingroup category..." (Turner et al., 1987, p. 49). Still, in more recent work, Hornsey (2008, p. 208) and even Turner et al. (2006, pp. 13-14) talk of the continuum being replaced in the late 1980 s by "the idea of different levels of selfcategorization", suggesting a categorical rather than continuous view of the SPID. Finally, it is important to highlight that none of these conceptual developments in self-categorization theory seem to have substantively affected framings of the SPID in organizational psychology, which as evidenced by Table 1, continue to adopt a largely content-based, dichotomous perspective (though see Ashforth, 2007).

\section{Summary}

Four key insights emerge from this exploration of the SPID's framing in organizational psychology, and its origins and evolution in the social identity approach. First, the SPID originated from a source other than those it is typically linked to in contemporary identity research. While sources such as Ashforth and Mael (1989), Tajfel and Turner (1979), and Turner (1982) are often linked to the dichotomy, my review suggests that a little-cited chapter by Gordon (1968) is likely the original source of the SPID ${ }^{2}$. Second, while the enduring, content-based framing of the SPID in organizational psychology is consistent with early views of the SPID in social identity theory (Turner, 1982), it lacks the emphasis on context and dynamism that characterizes later conceptualizations of the SPID in self-

\footnotetext{
2 It is worth noting that at the time of writing, Google scholar has recorded only 434 citations of the Gordon (1968) chapter - a vastly lower figure than the 4,765 and 13,676 citations recorded for the Turner (1982) chapter and Ashforth and Mael (1989) article, respectively.
} 


\section{REFRAMING THE SOCIAL/PERSONAL IDENTITY DICHOTOMY}

categorization theory (Abrams, 1996; Simon, 1997; Turner et al., 1994). Third, there appears to be significant equivocality in the self-categorization literature as to the precise nature of the relationship between social and personal identity, and in particular, as to whether they exist in dichotomous relationship with one another, or occupy opposing poles of a continuum. Finally, while contemporary references to the SPID in organizational psychology (see Table 1) typically present it as the way of classifying identities, by tracing its origins and evolution, I have shown that the SPID first emerged as a hypothetical heuristic, and seems to have endured without ever being subject to serious empirical testing. If, as I argue, the SPID is but one way we might categorize a person's various identities, it is incumbent on scholars to critically evaluate its value for understanding the nature, dynamics, and consequences of identities.

\section{Strengths and Limitations of the Social/Personal Identity Dichotomy}

As explained in the preceding section, two broad framings of the SPID are common in the identity literature, with a content-based framing predominating in organizational psychology, and a more dynamic, context-based framing evolving in social psychology. Below, I critically evaluate both of these framings of the SPID, focusing first on the contentbased framing and subsequently on the context-based framing.

\section{Strengths and Limitations of a Content-Based Framing of the SPID}

A content-based framing of the SPID has several advantages, chief among these being face validity. As Vignoles (2019) observes, classifying an individual's various identities as either social or personal according to their content is heuristically appealing: each of us intuitively recognizes that we sometimes define ourselves with reference to those features that we think are unique to us as individuals, and other times, with reference to broader groups or collectives. In this sense, a content-based framing of the SPID provides a 


\section{REFRAMING THE SOCIAL/PERSONAL IDENTITY DICHOTOMY}

seemingly logical and efficient means of drawing broad-but-meaningful distinctions between two types of identity, each of which appear to have different sources and consequences.

A content-based framing of the SPID is also helpful in emphasizing that people construct identities around a variety of types of self-knowledge. Given the complexity of identity as a phenomenon, scholars must necessarily limit their focus to certain aspects or forms of identity in order to make research feasible. This selective focus on certain identities, however, can mean that we neglect other identities in our research, particularly newer ones that have emerged due to social and cultural changes (Walker \& Caprar, 2020). A contentbased framing of the SPID emphasizes that identities can be sourced from a diverse range of phenomena: some of which are seemingly external, "social" phenomena, such as social categories, groups, and networks, as well as seemingly more internal, "personal" sources, such as preferences, patterns of behavior, attitudes, and physical appearance. In this way, a content-based framing of the SPID harnesses what has always been a crucial strength of identity as a construct: its ability to facilitate consideration of both the self-aware individual and the social environment they occupy, along with the reciprocal impact of each on the other (Cooley, 1902; Blumer, 1969; Mead, 1934; Turner et al., 1987).

Despite its strengths, however, a key limitation of a content-based framing is that it does not definitively address what exactly distinguishes social from personal identities. Instead, this question is replaced with one that is equally conceptually thorny, albeit slightly more specific: what constitutes social versus personal identity content? Scholars tend to be ambiguous on this point, and as illustrated by the representations of the SPID in Table 1, often try to circumvent the issue by using multiple synonyms, so as to roughly triangulate what constitutes social identity content (e.g., self-knowledge concerning group membership, social roles, social categories, and so on) versus personal identity content (e.g., selfknowledge concerning traits, attributes, characteristics, and so on). The rationale for such a 


\section{REFRAMING THE SOCIAL/PERSONAL IDENTITY DICHOTOMY}

definitional approach is understandable, but this tendency to list many synonyms also means that we never arrive at a definitive answer as to what precisely constitutes social versus personal identity content.

One of the more robust approaches to distinguishing between social and personal identity content is to classify identities built around idiosyncratic self-knowledge as personal (e.g., "I am the first ever CEO of Company X"), and identities built around non-idiosyncratic self-knowledge as social (e.g., Thoits \& Virshup, 1997). The logic of this approach is somewhat problematic, however, because paradoxically, some knowledge of social group or category membership (i.e., non-idiosyncratic self-knowledge) must be invoked for idiosyncratic self-knowledge to exist. For instance, if an individual were to define themselves as "the first-ever CEO of Company X" (a truly idiosyncratic piece of self-knowledge, because a company can only have one "first-ever CEO"), this self-knowledge inevitably also locates the individual in the broader social groups of CEOs and Company X members. To classify this identity as personal based on its (seemingly) idiosyncratic content, then, is to conceal its implicit, but equally consequential social elements (see also Deaux [1993] and Reid and Deaux [1996]).

The key point here is that drawing sharp conceptual distinctions between "social" identity content on the one hand, and "personal" identity content on the other, is a difficult task - and one that relies heavily on the discretion of whomever is drawing the distinction. While some identities might be obviously and unequivocally social or personal in content (e.g., Trafimow, Triandis, \& Goto, 1991: Experiment 1), most identities seem to have both social and personal elements (Vignoles, 2019). Nearly three decades ago, for instance, Brewer (1991) proposed that people have a tendency to identify with groups that provide an optimal sense of distinctiveness from and similarity to others. More recent research demonstrates that identifying with groups can have significant consequences for individual 


\section{REFRAMING THE SOCIAL/PERSONAL IDENTITY DICHOTOMY}

health and well-being (Jetten, Haslam, Cruwys, Greenaway, Haslam, \& Steffens, 2017). Such research illustrates that even the most ostensibly social identities can be motivated by personal considerations, and have equally personal consequences.

A second limitation of a content-based framing of the SPID is its conceptual awkwardness when it comes to identities lacking in definitively social or personal content. Indeed scholars have long recognized that the SPID is not suited to dealing with identities constructed around one-to-one relationships, and as mentioned earlier, introduced a third type, relational (or interpersonal) identities, to capture forms of self-definition that fall between the social and personal levels (Brewer \& Gardner, 1996; Cooper \& Thatcher, 2010; Sluss \& Ashforth, 2007, 2008). Furthermore, individuals are known to construct identities around phenomena that are seemingly neither social nor personal (Vignoles, 2019), such as physical objects (Fischler, 1988; Kroger \& Adair, 2008), places (Proshansky, 1978), and organizational artefacts and practices (Ashforth, Moser, \& Bubenzer, 2020). By adhering to a content-based framing of the SPID, however, we risk seeing such identities as conceptual misfits, and subsequently overlooking them in our theorizing and research.

A final, and perhaps most significant limitation of a content-based framing of the SPID, is that it ignores the fact that any given identity, while ostensibly social in content, can be experienced in a personal way (and vice-versa). Consider, for instance, an individual who identifies as (amongst many other things) "hard-working". A content-based framing of the SPID would lead one to conclude that this constitutes a personal identity, as it seems to be an identity constructed around an individual trait (i.e., strong work ethic). By classifying the identity as personal based on its content, however, we risk overlooking the identity's potential to promote a sense of connection with others who share this trait. For instance, if the individual were attending an awards evening for diligent employees, their identity as a hardworker would likely prompt a social sense of belonging to a broader collective of hard- 


\section{REFRAMING THE SOCIAL/PERSONAL IDENTITY DICHOTOMY}

working individuals. If, on the other hand, the same individual were working in a team of "slackers", this same identity would likely prompt a personal sense of dissimilarity and separation from the others, of being the hard-working individual in the team. This simple example shows how classifying an identity as social or personal on a content-basis risks concealing how individuals actually experience said identity, and importantly, how the nature of this experience changes dynamically over time. While this is a major limitation of a content-based framing of the SPID, as I discuss next, it is the primary advantage of the more experiential, context-based framing of the SPID that evolved in self-categorization theory.

\section{Strengths and Limitations of a Context-Based Framing of the SPID}

As discussed earlier, the version of the SPID that evolved in self-categorization theory was a significant departure from Gordon (1968) and Turner's (1982) original content-based view, with social and personal identity instead coming to be viewed more as dynamic, psychological states (e.g., Abrams, 1996, 1999; Reicher et al., 1995; Simon, 1997; Turner et al., 1994). This updated framing overcomes many of the limitations of the content-based framing of the SPID canvassed above. Most crucially, it acknowledges that people experience the same identity in different ways, depending on the social context they occupy at any given moment. In addition, by focusing on the experience of identities rather than their content, the context-based framing also makes drawing distinctions between social and personal identity a matter of empirical study rather than researcher discretion.

A critical limitation of the framings of the SPID that emerged in self-categorization theory, though, is that, as explained earlier, there remains ambiguity as to whether social and personal identity are best understood as two levels of a dichotomy, or opposing poles of a continuum. This is a significant distinction, because each of these framings suggests a different understanding of how people experience their identities. With a dichotomous framing, we assume people can think in terms of "me" and "we", but never both 


\section{REFRAMING THE SOCIAL/PERSONAL IDENTITY DICHOTOMY}

simultaneously. In addition, a dichotomous framing does not allow for the experience of varying degrees of "me-ness" or "we-ness". Both of these features, however, are absent from a continuous framing, which allows for mixed senses of "me-ness" and "we-ness". The ambiguity about this issue in the self-categorization literature therefore leaves a crucial question about the ontology of social and personal identity unanswered.

In addition, while Turner et al.'s (1987, p. 49) continuous framing of the SPID allows for individuals to experience a mix of social and personal identity, it nevertheless maintains a "functional antagonism" between the two. This view of social and personal identity as opposing poles of a single continuum makes it theoretically impossible for an individual to experience a single identity highly socially and highly personally. Yet research suggests this happens (Hornsey \& Jetten, 2004; Jetten, McAuliffe, Hornsey, \& Hogg, 2006; Jetten \& Postmes, 2006; Pickett \& Leonardelli, 2006). Identification with groups that endorse individualistic norms are an interesting illustration of this phenomenon. Jetten, Postmes, and McAuliffe (2002), for instance, found that the more North Americans identified with their (individualistic) culture, the more likely they were to endorse individualistic attitudes and preferences - a surprising finding in light of traditional social identity principles, which suggest that strong group identification is antithetical to individualism. Findings such as these support the notion that a single identity can simultaneously have both individualizing and socializing psychological consequences (Ashforth, 2007; Vignoles, 2019; Walker \& Caprar, 2020), and problematize the notion that social and personal identity exist in an antagonistic relationship.

\section{A Dynamic, Two-Dimensional Conceptualization of the Social and Personal Dimensions of Identity}

In an effort to overcome the limitations of the SPID discussed above, I outline here a modified conceptualization that has three defining elements: i) The social and personal dimensions of identity are best understood in terms of psychological experience (rather than 


\section{REFRAMING THE SOCIAL/PERSONAL IDENTITY DICHOTOMY}

identity content); ii) These dimensions are two independent continua (rather than two levels of a dichotomous variable, or opposing poles of a continuum); and (iii) These dimensions are dynamic: any given identity can vary in the extent to which it is experienced socially and/or personally over time and across contexts. I elaborate each of these elements in the following sections, and in doing so, explain how this modified conceptualization retains the most theoretically useful elements of the various framings of the SPID, whilst overcoming their deficiencies.

Before elaborating, though, I clarify some terms and basic assumptions. I herein use the terms "social dimension of identity" and "personal dimension of identity" because, as showcased in the earlier review, the terms "social identity" and "personal identity" have been subject to many different interpretations through the years. Whilst acknowledging the risks of construct proliferation (e.g., Podsakoff, MacKenzie, \& Podsakoff, 2016), this interpretive ambiguity supports the case for a semantic refresh: fresh terms allow for new, more precise meanings that are unmuddied by any earlier interpretations. Second, I assume that an identity is highly meaningful self-knowledge that is used for self-definitional purposes (e.g., Tajfel \& Turner, 1979; Walker \& Caprar, 2020). I further assume that each individual has myriad identities (Ramarajan, 2014), which move in and out of psychological awareness over time and across contexts (Oakes, 1987), and that each of these identities can vary along myriad dimensions - two of which are the social and personal dimensions.

\section{Element \#1: The Social and Personal Dimensions of Identity are Best Understood in Terms of Psychological Experience}

The first assumption of the approach I outline is that the social and personal dimensions of identities are best understood in terms of psychological experience. When an individual is experiencing an identity socially, I mean that the focal identity is psychologically experienced in a way that makes a person see themselves as part of a corresponding social entity (e.g., dyad, group, network, category) in that particular moment. 


\section{REFRAMING THE SOCIAL/PERSONAL IDENTITY DICHOTOMY}

When an individual is experiencing an identity personally, I mean that an identity is psychologically experienced in a way that makes a person see themselves as an individual embodiment of the identity in that particular moment. Put simply, an identity is experienced socially when it leads an individual to think and feel in terms of "we" (e.g., "we" as teachers), and personally when it leads an individual to think and feel in terms of "me" (e.g., "me" as a teacher).

Note that I assume here a distinction between an identity simply becoming salient on the one hand (i.e., coming into psychological awareness), and the more enduring (though still context-sensitive and dynamic) psychological experience of this identity on the other.

Consistent with self-categorization theory (Oakes, 1987), then, I assume that certain basic features of an individual (e.g., their immediate goals/needs), their identities (e.g., the accessibility of each identity), and their immediate context (e.g., the relevance or "fit" of a given identity with said context) all contribute to bringing any given identity to one's awareness at a particular moment. Much work has explored the basic issue of salience of selfcategorizations (e.g., Abrams, Thomas, \& Hogg, 1990; Oakes, 1987; Oakes \& Turner, 1986; Turner et al., 1994; van Dick, Wagner, Stellmacher, \& Christ, 2005), but my focus here is on a related though qualitatively different phenomenon: the psychological experience that immediately follows from an identity becoming salient. Researchers should also be cautious of conflating the social experience of an identity with a sense of belonging, and personal experience with a sense of distinctiveness: consistent with existing perspectives (Vignoles, 2009), each experience of an identity could lead to either or even both belonging and distinctiveness, depending on the features of the identity in question and other contextual considerations.

This experiential framing of the social and personal dimensions intentionally departs from the content-based framing of the SPID that predominates in organizational psychology. 


\section{REFRAMING THE SOCIAL/PERSONAL IDENTITY DICHOTOMY}

A critical advantage of an experiential approach is that it makes the social and personal dimensions of identity significantly more amenable to empirical investigation. If a researcher wants to know the extent to which a person experiences a given identity socially or personally, they can use various research techniques to find out - the most obvious of which would be to ask the individual. The empirically-rooted nature of the experiential approach therefore overcomes a key limitation of the content-based framing of the SPID - its ambiguity about the issue of what exactly distinguishes social from personal identity content. With an experiential approach, questions about the "social-ness" or "personal-ness" of identities are not answered via researcher judgment, but rather via data about how individuals experience their identities.

While this experiential approach differs from content-based framings of the SPID, it is similar to the framing of the SPID that evolved in self-categorization theory (Simon, 1997; Turner et al., 1987). A subtle, but potentially important difference between the two, though, is that the framing of the SPID from self-categorization theory nevertheless assumes a distinction between social and personal identities. The approach I outline here, however, does not set the social/personal distinction at the level of identity, but at the more specific level of identity dimensions. I do this because it better aligns with existing perspectives on identity in organizational psychology: it is generally assumed that all individuals have multiple identities derived from various sources (Ramarajan, 2014), and which, I propose here, all vary along multiple dimensions - two of which are the social and personal dimensions. From this standpoint, then, individuals are not viewed as experiencing social and/or personal identities, but rather as having multiple identities, each of which they experience as varying degrees of social and/or personal over time.

\section{Element \#2: The Social and Personal Dimensions of Identity are Two Independent Continua}




\section{REFRAMING THE SOCIAL/PERSONAL IDENTITY DICHOTOMY}

The second and most novel element of the approach I outline here is that it treats the social and personal dimensions of identity as two independent continua. This again departs from the framing of the SPID that predominates in organizational psychology, which treats social and personal identity (however conceived) as two levels of a dichotomous variable (Abrams, 1999; Ashforth \& Mael, 1989; Gordon, 1968; Turner, 1982). As mentioned earlier, a range of empirical findings show that individuals can derive a mix of individuality and sociality from one identity (Hornsey \& Jetten, 2004; Jetten, McAuliffe, Hornsey, \& Hogg, 2006; Jetten \& Postmes, 2006). Such findings counter the dichotomous view of social and personal elements of identity, but are more consistent with the conceptualization of the social and personal elements of identity as opposing poles of a single continuum (Turner et al., 1987).

As explained earlier, though, a unidimensional approach disavows the possibility of an individual experiencing a single identity highly socially and highly personally at any given moment. This is one reason why I am specifically proposing a bivariate (i.e., two dimensional) view of the social and personal dimensions of identity, as it allows for such a possibility. Cacioppo and Berntston (1994) make the same argument in respect of attitudes, and present three key arguments as to the theoretical utility of a bivariate approach.

First, and most crucially, a two-dimensional approach allows researchers to more precisely capture individuals' psychological experiences. Figure 1 depicts a simple example to illustrate this point in respect of the social and personal dimensions of identity. Imagine an individual, Alice, who is asked at four points in time to report the extent to which her identity as a Google employee makes her feel like an individual embodiment of the category (i.e., is experienced personally) and part of the broader collective of Google employees (i.e., is experienced socially). Imagine also that Alice's self-reported data is assessed using two continuous scales: one to capture variation along the social dimension, and the other to 


\section{REFRAMING THE SOCIAL/PERSONAL IDENTITY DICHOTOMY}

capture variation along the personal dimension, resulting in the square markers shown in Figure 1. Now suppose instead that this same data was collected using a single, bipolar social-personal scale. Alice's experiences of her identity would necessarily be reported (and subsequently interpreted for analytical and theoretical purposes), only in terms of variation along the diagonal dashed line, meaning that as her identity becomes more social, it is assumed to becomes less personal, and vice-versa. As a result, Alice's experience of her identity at Time 1 (as not particularly social or personal) and Time 3 (as highly social and highly personal) would be artificially transposed (represented by the dotted line), and represented at the same point on the bipolar scale (the round marker), despite being drastically different psychological experiences of the identity. This example highlights how a bivariate approach allows identity researchers to theorize about and empirically capture experiences of identity at all possible positions in this two-dimensional space, without misrepresenting them.

Insert Figure 1 here

Related to the above point, a bipolar continuum is ambiguous as to the psychological meaning of the mid-point. In respect of attitudes, for instance, Cacioppo and Berntson (1994) point out that "neutral, indifferent, and ambivalent attitudes may all have similar manifestations on bipolar attitude scales despite the differences in the evaluative substrates and behavioral ramifications of each" (p. 406). Similar ambiguities arise when considering the mid-point of a single, social-personal identity continuum: if an individual reports being at the mid-point, does that mean they are in a neutral state (i.e., not presently experiencing a given identity either socially or personally), or rather experiencing the identity extremely socially and extremely personally, resulting in a "cancelling out" effect? Without further inquiry, researchers cannot answer these questions. No such ambiguity arises with a two- 


\section{REFRAMING THE SOCIAL/PERSONAL IDENTITY DICHOTOMY}

dimensional approach, however, where these more complex experiences of an identity are not only allowed for, but systematically captured, and can be incorporated into theorizing and research.

Finally, conceptualizing the social and personal dimensions as two dimensions encourages consideration of not one but four types of variation, which I represent visually in Figure 2 (see Cacioppo and Berntson [1994] for a more extensive discussion of this issue). These four types of variation are: i) independent variation along the personal (but not the social) dimension; ii) independent variation along the social (but not the personal) dimension; iii) antagonistic variation along the social and personal dimensions (i.e., a simultaneous increase on one dimension and decrease on the other); and iv) coactive variation along the social and personal dimensions (i.e., a simultaneous increase or decrease on both dimensions). This is a crucial point because to date, the predominance of the SPID (in all its framings) has meant that identity research has mostly focused on understanding antagonistic variation along the social and personal dimensions, with much less research focusing on the three other forms of variation.

Insert Figure 2 here

Perhaps the most provocative of these other three forms of variation is the notion of coactive variation, which explicitly allows for the possibility of a given identity simultaneously being experienced highly socially and highly personally. None of the framings of the SPID canvassed earlier allow for such a possibility. Relatedly, optimal distinctiveness theory posits that people strive for and can thus attain moderate (i.e., optimal) degrees of distinctiveness and inclusion from a single identity, but explicitly disavows the possibility of a single identity conferring high degrees of both (see Figure 2 in Brewer, 1991). Given the apparent consistency on this issue across these classic perspectives on identity, 


\section{REFRAMING THE SOCIAL/PERSONAL IDENTITY DICHOTOMY}

many may justifiably wonder: can people actually experience a single identity highly socially and highly personally at the same time? A range of more recent research suggests this to be the case (Hornsey \& Jetten, 2004; Jetten \& Postmes, 2006; Vignoles, 2009). From a classic social identity standpoint, substantial theoretical legwork is required to account for such findings (see Turner et al., 2006). Not so with a two-dimensional approach, however, which deliberately allows for the possibility of an individual simultaneously experiencing a single identity highly socially and highly personally.

This notion of coactive variation has particular implications for experimental research on identity, where it is often assumed that, momentarily reverting to SPID-centric terms, a manipulation intended to make social identity salient necessarily blocks personal identity becoming salient (e.g., Frisch, Häusser, van Dick, \& Mojzisch, 2014; Häusser, Kattenstroth, van Dick, \& Mojzisch, 2012). But what if certain manipulations have the (unintended) effect of triggering positive coactivation: that is, making an individual experience a single identity highly socially and highly personally? Both Frisch et al. (2014) and Häusser et al. (2012), for instance, find that stress is reduced when identification with a support group is experimentally induced. Notably, one of the tasks comprising the social identity manipulation in both studies required participants to independently generate solutions to a problem (i.e., improving life in one's city or university), with participants also being told that problemsolving performance would ultimately be judged on the basis of the group's performance. This latter element is presumed by the researchers to induce social identification, yet the potential psychological significance of the first element should not be overlooked.

Participants in these conditions solve problems as individuals and anticipate judgement at the level of collective performance, which could have led to a social and personal experience of the same identity (e.g., "me, the individual contributor to my group's performance" and "we, the group who will be judged on our problem-solving performance"). This in-turn could have 


\section{REFRAMING THE SOCIAL/PERSONAL IDENTITY DICHOTOMY}

contributed to the studies' findings regarding stress attenuation: perhaps support from a group reduces stress when individuals identify with the group and also experience the identity in a way that fosters a sense of individual agency (i.e., an ability to deal with the stressor independently). The studies would not have detected any such effects, however, because by virtue of the assumed antagonistic relationship between social and personal identity embedded in the SPID, the researchers would have not thought to look for them. In contrast, the two-dimensional approach introduced here encourages consideration of such effects as a matter of course.

\section{Element \#3: Social and Personal Experiences of Identity are Dynamic}

The final assumption of the approach I outline here is that identities vary in the extent to which they are experienced socially and/or personally across time and situations. Unlike the content-based framing of the SPID, then, it is not assumed that identities have a fixed social or personal essence, nor a fixed level of "social-ness" or "personal-ness". Instead, similar to the view of the SPID that emerged in self-categorization theory (Simon, 1997; Turner, 1985; Turner et al., 1987), it is assumed here that the social and personal experience of identities is dynamic.

What factors are likely to drive change along the social and/or personal dimensions of identity? Comprehensively answering this question is a matter for future theorizing and research, but as a high-level answer, such variation would seem to arise from changes in psychological context - a distinct consideration from objective context. Objective and psychological context will align closely at times, perhaps even most of the time, but be misaligned at others. An individual who identifies as gay, for instance, might believe they are the only gay person in a meeting about their company's diversity and inclusion initiatives, despite there actually being several other meeting participants who also share this identity. Nevertheless, their perception of the context and their identity's place within it (i.e., that they 


\section{REFRAMING THE SOCIAL/PERSONAL IDENTITY DICHOTOMY}

are the only gay person in the meeting) causes them to experience this identity in a personal way, which influences their subsequent thoughts, feelings, and behavior. In addition, people frequently imagine future and reflect on past psychological contexts, which further supports a focus on psychological over objective context.

As explained earlier, a two-dimensional approach to the social and personal dimensions of identity allows for four main types of variation (see Figure 2). Because of these multiple forms of variation, theorizing about identity dynamics requires more sophistication than with a dichotomous or unidimensional approach, where one need only canvas what factors make an identity social or personal, or more social/less personal (and vice-versa), respectively. As a heuristic to guide this more complex theorizing, then, it may be helpful to distinguish between those psychological contexts that enable each type of variation depicted in Figure 2 on the one hand, and the more specific features of these enabling contexts that determine the magnitude of any subsequent variation on the other.

To illustrate how this heuristic can be used for theorizing, let us briefly consider what might enable and magnify an identity's independent variation along its personal dimension (i.e., with no impact on its place on the social dimension). One psychological context (of potentially many) that could enable such variation are those where one recognizes an identity is not merely uncommon, but fully unique to them, which have been a core focus of research on stigma (Clair et al., 2005; Summers et al., 2018) and tokenism (Kanter, 1977) in organizations. In these situations, the salient identity marks one out as singularly distinct from all others, while the psychological absence of others who share the identity minimizes the likelihood of experiencing the identity socially. Yet while the "me and them" quality of the context creates the potential for (i.e., enables) independent variation along the personal dimension, the magnitude of such variation might be shaped (at least partly) by the perceived number of people who lack the identity in such a context: it is one thing, for instance, for an 


\section{REFRAMING THE SOCIAL/PERSONAL IDENTITY DICHOTOMY}

employee to believe they are the only gay person in a meeting of five, another to perceive this in a meeting of thirty, and still another to perceive this in a company town hall of fourhundred people. Variation along the personal dimension might also be magnified by the extent to which one perceives the context is comprised not merely of non-identifiers, but also by the extent to which they perceive such non-identifiers hold hostile or favorable attitudes towards the focal identity. In terms of hostility, "me versus them" scenarios are perhaps the most threatening social situations one can encounter: not only do they entail confronting a group of others with potential to cause harm to oneself, but they also necessitate doing this alone. On the other hand, situations where a given identity marks one out as positively unique represent a valuable opportunity for self-enhancement (Sedikides \& Gregg, 2008). From an evolutionary standpoint, then, it would seem logical for the mind to have developed a mechanism — such as the ability to heighten the personal (but not the social) experience of an identity — that would alert one to such circumstances, and prime one to take selfpreservative action (in the case of hostility), or maximize the opportunity for selfenhancement (in the case of favorability). In the case of hostility, one such action may be an effort to balance out the highly personal experience of the identity by finding ways of heightening the social experience of it (e.g., trying to find "common ground" with hostile non-identifiers), a similar phenomenon to that well-documented in research on optimal distinctiveness theory (Leonardelli, Pickett, \& Brewer, 2010).

A focus on different aspects of psychological context as a driver of how people experience their identities, as illustrated in the example above, suggests an expansion of the way the outcomes of identities are generally understood and studied in organizational psychology. Identity research within organizational psychology commonly focuses on one's general level of identification with different work-related targets (e.g., teams, organizations, professions) (e.g., Ciampa et al., 2019; van Dick et al., 2006; van Dick et al., 2007). 


\section{REFRAMING THE SOCIAL/PERSONAL IDENTITY DICHOTOMY}

Hypotheses in empirical studies often then suggest that the more-or-less an individual identifies with a certain target, the more-or-less likely they are to think $\mathrm{X}$, feel $\mathrm{Y}$, or do $\mathrm{Z}$ (see van Knippenberg, 2000). These predictions are usually tested using a between-persons design, and self-reported measures of identification (e.g., Hirst et al., 2009). The dynamic nature of the current approach, however, suggests that in order to comprehensively understand the work-related outcomes of any given identity, we need also consider how changes in psychological context (throughout the day, week, month, and even year) alter one's experience of the identity, and how these varied experiences lead to different outcomes. Identification with organizations, for instance, is typically framed as a "social" identity, and assumed to drive people to work harder on behalf of the organization when the identification is made salient (Ashforth et al., 2008; van Dick et al., 2005; van Knippenberg, 2000). While this logic might hold in contexts where one experiences the identity socially (though see Conroy, Henle, Shore, \& Stelman, 2017), what happens in contexts that enable a highly personal, non-social experience of the identity? If an individual is made to feel like the "odd one out" because of their organizational membership (e.g., being the only Harvard graduate at a particular event), and perceives this is viewed favorably by others in that context (e.g., facilitating a workshop for students wishing to apply to Harvard), this highly personal experience of the organizational identification is likely to be an affirming, motivating experience. However, if they perceive their unique identity constitutes a negative attribute in that context (e.g., a Harvard graduate attending a seminar on the role of Ivy League universities in perpetuating inequality), the lack of a sense of "we, Harvard graduates" may dampen the individual's capacity to deploy the usual identity threat responses (e.g., Brown \& Coupland, 2015; Petriglieri, 2011), making them more prone to feeling resentment towards the organization. This resentment could in-turn, and contrary to the dominant perspective on organizational identification, reduce one's motivation to work 


\section{REFRAMING THE SOCIAL/PERSONAL IDENTITY DICHOTOMY}

harder on the organization's behalf, at least for as long as it endures in one's mind. These are no doubt simplified examples, but they help to highlight the theoretical value of focusing on how changes in psychological context can trigger radically different experiences of the same identity.

\section{Discussion}

The SPID has endured for decades as a tool for classifying identities in organizational and social psychology. Perhaps because of this ubiquity, however, scholars have rarely explored more critical questions about its utility for understanding identities (though see Vignoles, 2019). I have argued that despite its heuristic value, the SPID, in all its various framings, has certain conceptual limitations, suggesting a need for a modified approach. To this end, I introduced a dynamic, two-dimensional conceptualization of the social and personal dimensions of identity, which I argue facilitates a deeper understanding of how individuals experience their identities. I conclude by discussing the implications of this modified conceptualization for theory and research on identity.

\section{Theoretical Implications}

While the SPID is a longstanding approach to classifying identities (e.g., Ashforth \& Mael, 1989, Gordon, 1968; Turner, 1982), its continued use limits scholars' ability to fully understand the nature, dynamics, and consequences of identities. Arguably the most significant limitations of the content-based framing of the SPID that predominates in organizational psychology are: 1) its assumption that any given identity is, inherently and permanently, either social or personal in nature; 2) the high degree of researcher discretion involved in determining what constitutes social or personal identity content; and 3) its oversight of the psychological experience of identities. The dynamic, experiential approach outlined in this article overcomes these limitations by reframing the social and personal dimensions of identity as two continua, which captures the extent to which any given identity 


\section{REFRAMING THE SOCIAL/PERSONAL IDENTITY DICHOTOMY}

makes a person feel like part of a broader social entity (i.e., is experienced socially) and an individual entity (i.e., is experienced personally) at any given moment. This approach is theoretically advantageous because: 1) it allows researchers to capture changes in people's social and personal experiences of an identity over time and across contexts; 2) it acknowledges that one can experience an identity both socially and personally at any given moment (Hornsey \& Jetten, 2004; Vignoles, 2019); and 3) questions about the "social-ness" or "personal-ness" of identity are necessarily answered via empirical evidence rather than researcher judgment. In this way, the approach facilitates efforts to understand the intricacies of how individuals experience their identities in the course of organizational life.

Second, it is well-established that while individuals have multiple identities, not all of these identities are psychologically activated — and consequently impact thoughts, feelings, and behavior - at every moment (Ashforth et al., 2008; Higgins, King, \& Mavin, 1982; Hong, Morris, Chiu, \& Benet-Martinez, 2000; Markus \& Wurf, 1987; Oakes, 1987; van Dick et al., 2005). What has received far less consideration, however, is the notion that identities vary not only in level of activation (i.e., salience) over time, but also in how they are experienced subsequent to each instance of activation. The experiential approach outlined in this article acknowledges this dynamic by allowing for the same identity to be experienced in various ways across contexts. Acknowledging this point is particularly crucial for understanding the nature and consequences of identities in organizations, where individuals move through multiple social contexts in a single day, and in-turn experience the same identity in different ways over time.

An important issue to address at this point is what the approach outlined in this article means for scholars working from the standpoints of social identity theory, self-categorization theory, and optimal distinctiveness theory. By reframing the SPID, which in some form is an element of all these theories, the approach outlined in this article also suggests a reframing of 


\section{REFRAMING THE SOCIAL/PERSONAL IDENTITY DICHOTOMY}

what phenomena these research streams have (and have not) focused on to date, which in turn illuminates intriguing new research possibilities. Specifically, the approach encourages scholars to understand these classic paradigms as focused largely on identities that are typically experienced socially - a subtle but important difference from a focus on inherently, exclusively, and enduringly "social identities". This raises an intriguing question that remains relatively unexplored across all of these classic paradigms: what psychological, behavioral, and group-related consequences do such identities have when experienced more personally than socially? I explore this question shortly when discussing future research directions.

Finally, the reframing of the SPID presented in this article facilitates greater exploration of intrapersonal identity dynamics in organizational contexts, a direction which others have highlighted as a priority for the field (e.g., Bednar et al., 2019; Miscenko \& Day, 2016). While much research within organizational psychology has focused on variance across individuals in the presence (or average level) of identification with different work-related targets (e.g., organizations, teams), and the links between such variation and different outcomes (e.g., Ashforth et al., 2008), the approach outlined in this article highlights the need to complement this wealth of between-person research with new studies of the within-person dynamics of identities over time. The guiding question of such a research programme would be something along the lines of "how does the psychological experience induced by a given identity, or constellation of identities, change over time and across contexts, and with what consequences for individuals, and the groups and organizations they belong to?" I have focused here on how individuals experience their identities more-or-less socially and personally, but researchers could also explore real-time variation along other dimensions (e.g., the extent to which an identity boosts/lowers self-esteem, subjective uncertainty, and one's sense of self-continuity, see Vignoles, 2011), so as to paint a richer theoretical picture of the within-person dynamics of identities in organizations. 


\section{REFRAMING THE SOCIAL/PERSONAL IDENTITY DICHOTOMY}

\section{Research Implications and New Directions}

The reframing of the SPID developed in this article has important implications for the methods used to study identities. As mentioned above, the approach encourages greater use of within-person designs in quantitative studies of identity, where the focus is on patterns of variation along the social and/or personal dimensions of identity over time, and associations between such patterns and relevant outcome variables. A technique ideally suited to such studies is experience sampling, where research subjects provide data about their psychological state at several time points in a single day (typically via a smartphone app). This method has grown in popularity in research on emotion (e.g., Fisher, Minbashian, Beckmann, \& Wood, 2013) and personality (e.g., Fleeson, 2007; Minbashian, Beckmann, \& Wood, 2018), but is uncommon in identity research. Experience sampling would allow researchers to track changes in how individuals experience a single identity in the course of the work day, and use various analytic techniques, such as hierarchical linear modelling and multilevel structural equation modelling, to assess how patterns of variation along the social and personal dimensions might relate to certain outcomes.

From a qualitative perspective, studies of identity in organizational psychology have excelled in modelling fairly high-level identity processes, such as how individuals construct and maintain identities (Kreiner, Hollensbe, \& Sheep, 2006; Pratt et al., 2006), manage multiple identities in work contexts (Vough, 2012), and deal with identity threat and/or loss (Brown \& Coupland, 2015; Vough, Bataille, Noh, \& Lee, 2015). More micro-level questions about how individuals experience these identities in the course of day-to-day life (i.e., at the level of specific thoughts and emotions), and importantly, how this experience changes as they move through social contexts have received less attention. The approach to the social and personal dimensions of identity outlined in this article highlights the importance of using qualitative techniques that capture and facilitate theorizing about these "micro-dynamics" of 


\section{REFRAMING THE SOCIAL/PERSONAL IDENTITY DICHOTOMY}

identity, such as diary studies, open-ended experience sampling, and analysis of social media data.

In terms of more specific research directions arising from this article, developing a parsimonious account of what factors both enable and magnify the four types of variation along the social and/or personal dimensions discussed earlier is a clear priority. Rather than trying to achieve this through empirical studies, a more efficient initial approach would be to thoroughly review relevant portions of the identity literature, as many clues are surely scattered across this literature regarding the drivers of the social and personal experience of identities. When seeking to discern enabling contexts of each form of variation through such a review, relevant considerations might be the social composition of any given study's research context (e.g., "me and them", intergroup, interpersonal) as well as the specific nature of the identities under study. For example, it seems likely that relational identities developed around a work relationship (Sluss \& Ashforth, 2007) would frequently be experienced as simultaneously highly social and personal (i.e., be subject to coactive variation), because both individuals are socially connected by the relationship (e.g., "we, mentor and mentee"), but each also has a distinct individual role, with particular meanings and responsibilities in the context of the relationship (e.g., "me, the mentor responsible for guiding and supporting my mentee").

When seeking to discern what features subsequently magnify variation along the social dimension, research on perceptions of group entitativity (i.e., what leads people to perceive a collection of people as a coherent, bonded unit) (e.g., Campbell, 1958; Lickel, Hamilton, \& Sherman, 2001) suggests a number of potentially relevant factors, including: the perceived number of proximal identifiers (i.e., people perceived to share the identity in question in any given context); the extent to which one perceives they share common goals and/or a common fate with proximal identifiers; the perceived level of dependence on and 


\section{REFRAMING THE SOCIAL/PERSONAL IDENTITY DICHOTOMY}

attraction to proximal identifiers; and the extent to which one perceive themselves to be similar to proximal identifiers on identity-relevant dimensions. In addition, I highlighted earlier some potential factors that might magnify variation along the personal dimension (i.e., perceived number of non-identifiers in a given context, perceived hostility/favorability of non-identifiers towards the focal identity), and future research should seek to test these ideas, as well as uncover the array of other factors relevant to this dynamic. Research intended to explore such issues should be sensitive to likely bidirectional effects. For example, while individuals might experience an identity more socially to the extent they perceive dependency on or similarity to others etc., a heightened social experience of the identity might reciprocally heighten such perceptions (see Jetten et al., 2017; Simon, Pantaleo, \& Mummendey, 1995).

The reframing of the SPID outlined in this article also illuminates new research possibilities by expanding our perspective on the consequences of identities that have to-date been considered "social" identities (e.g., organizational, workgroup, and team identifications). Because of an assumed social essence, scholars have tended to link and study such identities in relation to outcomes that in some way implicate the collective associated with the identity, such as organizational commitment (Riketta \& van Dick, 2005) and organizational citizenship behavior (van Dick et al., 2005, 2006). By acknowledging that these identities are sometimes experienced personally, however, a range of intriguing new research questions come to the fore: Under what conditions might organizational, team, or workgroup identifications promote individualistic (rather than collectivistic) attitudes and behavior? To what extent do such identifications fulfil individuals' needs for distinctiveness (in addition to belonging), and with what consequences for the teams and organizations they work within? What role(s) do such identities play in expressions of individuality in work and organizational contexts? By seeking answers to these and related questions, we begin to paint 


\section{REFRAMING THE SOCIAL/PERSONAL IDENTITY DICHOTOMY}

a more balanced picture of the consequences of work-related identities — one that acknowledges the potential of any given identity to both individualize and socialize (Jetten \& Postmes, 2006).

In addition, acknowledging that any given identity can function socially and personally supports the case for more research on identities that have typically been considered inherently "personal” by organizational scholars (Miscenko \& Day, 2016). Some intriguing questions in this regard include: In what kinds of organizational contexts and situations are identities based on traits, preferences, and attitudes experienced more socially than personally, thus facilitating group formation and collective action? What are the (functional and dysfunctional) outcomes for both individuals and organizations of such identities being experienced more personally than socially, and vice-versa? How and why might identities based on traits, attitudes, or preferences influence outcomes traditionally not associated with these types of identities, such as organizational citizenship behavior and commitment, or organizational identification? By considering such questions, organizational scholars begin to account for a broader range of identities in our theories.

In the interests of clarity, I limited my focus in this article to the social and personal dynamics of a single, salient identity. Yet as noted throughout, each individual has myriad identities (Ramarajan, 2014). Assuming simultaneous salience of multiple identities is possible (Rothbard \& Ramarajan, 2009), how does this affect the social and personal experience of these identities? It may be that individuals continue to experience each salient identity along its own set of social and personal dimensions, and then mentally "average" across the dimensions associated with each identity to arrive at an overall sense of "we-ness" and "me-ness" in any given context. Alternatively, and aligned with the concept of intersectionality (Cole, 2009), perhaps simultaneous salience of multiple identities triggers a qualitatively different experience of the social and personal dimensions, where individuals 


\section{REFRAMING THE SOCIAL/PERSONAL IDENTITY DICHOTOMY}

immediately experience an overall sense of "we-ness" and "me-ness" at the level of context, as opposed to separately at the level of each salient identity. Future research on these issues should also aim to account for the psychological experience of one identity being drastically altered by the activation of another: one's identity as a Google employee, for instance, might be experienced very differently depending on whether one's political identity is also salient (e.g., Grind \& MacMillan, 2018).

Finally, the view of the social and personal dimensions outlined in this article could help to foster integration of research on identity and personality (Stryker, 2007; Turner et al., 2006). Future research could explore whether certain individual differences are associated with a tendency to experience identities more/less socially and personally. Some especially relevant individual differences include the need to belong (Leary, Kelly, Cottrell, \& Schreindorfer, 2013), the need for uniqueness (Snyder \& Fromkin, 1977), and while not positioned as a trait in a global sense, the concept of identity fusion. Swann, Gomez, Seyle, Morales, and Huici (2009) state that when an individual becomes fused with a group, "the self-other barrier is blurred and the group comes to be regarded as functionally equivalent with the personal self." (p. 995). Note that a content-based framing of the SPID is implicit in this definition. In terms of the approach outlined in this article, however, it might be the case that identity fusion is more usefully understood as positive coactivation of a given identity along its social and personal dimensions. Indeed future research on the social and personal dimensions of identity could look to studies of the antecedents of identity fusion, which might hold clues as to the conditions that enable individuals to experience any given identity highly socially and highly personally.

\section{Conclusion}

In organizational psychology, the social/personal identity dichotomy has influenced which identities have attracted research attention, the outcomes scholars have linked to such 


\section{REFRAMING THE SOCIAL/PERSONAL IDENTITY DICHOTOMY}

identities, and the approaches and methods used to study such links. In light of the limitations of the dichotomy discussed in this article, however, its continued invocation seems untenable, at least without certain modifications. To this end, I have sought to reframe the social and personal dimensions of identities in a way that focuses on the psychological experience induced by any given identity, and how the nature of this experience varies over time and across contexts. In doing so, I hope to stimulate efforts to better understand how identities both individualize and foster social connection, as well as the dynamic nature of people's experience of their identities in and around organizations. 
REFRAMING THE SOCIAL/PERSONAL IDENTITY DICHOTOMY

\section{References}

Abrams, D. (1996). Social identity, self as structure and self as process. In W. P. Robinson (Ed.), Social groups \& identities: Developing the legacy of Henri Tajfel (pp. 143-167). Butterworth Heinemann.

Abrams, D. (1999). Social identity, social cognition, and the self: The flexibility and stability of self-categorization. In M. A. Hogg \& D. Abrams (Eds.), Social identity and social cognition (pp. 197-229). Blackwell.

Abrams, D., Thomas, J., \& Hogg, M. A. (1990). Numerical distinctiveness, social identity and gender salience. British Journal of Social Psychology, 29(1), 87-92. https://doi.org/10.1111/j.2044-8309.1990.tb00889.x

Albert, S., Ashforth, B. E., \& Dutton, J. E. (2000). Organizational identity and identification: Charting new waters and building new bridges. Academy of Management Review, 25(1), $13-17$.

Alvesson, M., Ashcraft, K. L., \& Thomas, R. (2008). Identity matters: Reflections on the construction of identity scholarship in organization studies. Organization, 15(1), 5-28. https://doi.org/10.1177/1350508407084426

Ashforth, B. E. (2007). Identity: The elastic concept. In C. A. Bartel, S. L. Blader, \& A. Wrzesniewski (Eds.), Identity and the modern organization (pp. 85-96). Psychology Press.

Ashforth, B. E., Harrison, S. H., \& Corley, K. G. (2008). Identification in organizations: An examination of four fundamental questions. Journal of Management, 34(3), 325-374. https://doi.org/10.1177/0149206308316059

Ashforth, B. E., \& Humphrey, R. H. (1993). Emotional labor in service roles: The influence of identity. Academy of Management Review, 18(1), 88-115. https://doi.org/10.2307/3069328

Ashforth, B. E., \& Kreiner, G. E. (1999). "How can you do it?": Dirty work and the challenge of constructing a positive identity. Academy of Management Review, 24(3), 413-434.

Ashforth, B. E., \& Mael, F. (1989). Social identity theory and the organization. Academy of Management Review, 14(1), 20-39.

Ashforth, B. E., Moser, J. R., \& Bubenzer, P. (2020). Identities and identification: Beyond our fixation on the organization. In A. D. Brown (Ed.), The Oxford handbook of identities in organizations (pp. 817-832). Oxford University Press.

Ashforth, B. E., Schinoff, B. S., \& Brickson, S. L. (2020). "My company is friendly," "mine's a rebel": Anthropomorphism and shifting organizational identity from "what" to "who." Academy of Management Review, 45(1), 29-57.

https://doi.org/10.5465/amr.2016.0496 


\section{REFRAMING THE SOCIAL/PERSONAL IDENTITY DICHOTOMY}

Ashforth, B. E., Schinoff, B. S., \& Rogers, K. M. (2016). "I identify with her," "I identify with him": Unpacking the dynamics of personal identification in organizations. Academy of Management Review, 41(1), 28-60. https://doi.org/10.5465/amr.2014.0033

Bednar, J. S., Galvin, B. M., Ashforth, B. E., \& Hafermalz, E. (2019). Putting identification in motion: A dynamic view of organizational identification. Organization Science. Advanced online publication: https://doi.org/10.1287/orsc.2018.1276

Blumer, H. (1969). Symbolic interactionism: Perspective and method. Prentice-Hall.

Bolinger, A. R., Klotz, A. C., \& Leavitt, K. (2018). Contributing from inside the outer circle: The identity-based effects of noncore role incumbents on relational coordination and organizational climate. Academy of Management Review, 43(4), 680-703. https://doi.org/10.5465/amr.2016.0333

Brewer, M. B. (1991). The social self: On being the same and different at the same time. Personality and Social Psychology Bulletin, 17(5), 475-482.

Brewer, M. B., \& Gardner, W. (1996). Who is this "we"? Levels of collective identity and self representations. Journal of Personality and Social Psychology, 71(1), 83-93.

Brickson, S. L. (2000). The impact of identity orientation on individual and organizational outcomes in demographically diverse settings. Academy of Management Review, 25(1), 82-101.

Bridgman, T., Cummings, S., \& Ballard, J. (2019). Who built Maslow's pyramid? A history of the creation of management studies' most famous symbol and its implications for management education. Academy of Management Learning \& Education, 18(1), 81-98.

Brown, A. D. (1997). Narcissism, identity, and legitimacy. Academy of Management Review, 22(3), 643-686.

Brown, A. D. (2014). Identities and identity work in organizations. International Journal of Management Reviews, 17(1), 20-40. https://doi.org/10.1111/ijmr.12035

Brown, A. D., \& Coupland, C. (2015). Identity threats, identity work and elite professionals. Organization Studies, 36(10), 1315-1336.

Cable, D. M., Gino, F., \& Staats, B. R. (2013). Breaking them in or eliciting their best? Reframing socialization around newcomers' authentic self-expression. Administrative Science Quarterly, 58(1), 1-36. https://doi.org/10.1177/0001839213477098

Cacioppo, J. T., \& Berntson, G. G. (1994). Relationship between attitudes and evaluative space: A critical review, with emphasis on the separability of positive and negative substrates. Psychological Bulletin, 115(3), 401-423. https://doi.org/10.1037//00332909.115.3.401

Campbell, D. T. (1958). Common fate, similarity, and other indices of the status of aggregates of persons as social entities. Behavioral Science, 3, 14-25.

https://doi.org/10.1002/bs.3830030103 
Caza, B. B., Vough, H., \& Puranik, H. (2018). Identity work in organizations and occupations: Definitions, theories, and pathways forward. Journal of Organizational Behavior, 39(7), 889-910. https://doi.org/10.1002/job.2318

Ciampa, V., Sirowatka, M., Schuh, S. C., Fraccaroli, F., \& van Dick, R. (2019). Ambivalent identification as a moderator of the link between organizational identification and counterproductive work behaviors. Journal of Business Ethics, 169(1), 119-134. https://doi.org/10.1007/s10551-019-04262-0

Clair, J. A., Beatty, J. E., \& Maclean, T. L. (2005). Out of sight but not out of mind: Managing invisible social identities in the workplace. Academy of Management Review, 30(1), 78-95.

Cole, E. R. (2009). Intersectionality and research in psychology. American Psychologist, 64(3), 170-180. https://doi.org/10.1037/a0014564

Conroy, S., Henle, C. A., Shore, L., \& Stelman, S. (2017). Where there is light, there is dark: A review of the detrimental outcomes of high organizational identification. Journal of Organizational Behavior, 38(2), 184-203. https://doi.org/10.1002/job.2164

Cooley, C. H. (1902). Human nature and the social order. Charles Scribner's Sons.

Cooper, D., \& Thatcher, S. M. B. (2010). Identification in organizations: The role of selfconcept orientations and identification motives. Academy of Management Review, 35(4), $516-538$.

Deaux, K. (1993). Reconstructing social identity. Personality and Social Psychology Bulletin, 19(1), 4-12. https://doi.org/10.1177/0146167293191001

Dutton, J. E., Roberts, L. M., \& Bednar, J. (2010). Pathways for positive identity construction at work: Four types of positive identity and the building of social resources. Academy of Management Review, 35(2), 265-293.

Ellemers, N., De Gilder, D., \& Haslam, S. A. (2004). Motivating individuals and groups at work: A social identity perspective on leadership and group performance. Academy of Management Review, 29(3), 459-478.

Elsbach, K. D., \& Flynn, F. J. (2013). Creative collaboration and the self-concept: A study of toy designers. Journal of Management Studies, 50(4), 515-544.

https://doi.org/10.1111/joms.12024

Fischler, C. (1988). Food, self and identity. Anthropology of Food, 27(2), 275-292.

Fisher, C. D., Minbashian, A., Beckmann, N., \& Wood, R. E. (2013). Task appraisals, emotions, and performance goal orientation. Journal of Applied Psychology, 98(2), 364373. https://doi.org/10.1037/a0031260

Fleeson, W. (2007). Situation-based contingencies underlying trait-content manifestation in behavior. Journal of Personality, 75(4), 825-862. https://doi.org/10.1111/j.14676494.2007.00458.x 


\section{REFRAMING THE SOCIAL/PERSONAL IDENTITY DICHOTOMY}

Frisch, J. U., Häusser, J. A., van Dick, R., \& Mojzisch, A. (2014). Making support work: The interplay between social support and social identity. Journal of Experimental Social Psychology, 55, 154-161. https://doi.org/10.1016/j.jesp.2014.06.009

Froidevaux, A., Hirschi, A., \& Wang, M. (2018). Identity incongruence and negotiation in the transition from work to retirement: A theoretical model. Organizational Psychology Review, 8(4), 228-255. https://doi.org/10.1177/2041386619830754

Gergen, K. J. (1971). The concept of self. Holt, Rinehart and Winston.

Giessner, S. R., Ullrich, J., \& van Dick, R. (2011). Social identity and corporate mergers. Social and Personality Psychology Compass, 5(6), 333-345. https://doi.org/10.1111/j.1751-9004.2011.00357.x

Gordon, C. (1968). Self-conceptions: Configurations of content. In C. Gordon \& K. J. Gergen (Eds.), The self in social interaction - Volume I: Classic and contemporary perspectives (pp. 115-136). John Wiley \& Sons.

Grind, K., \& MacMillan, D. (2018). Google vs. Google: How nonstop political arguments rule its workplace. Retrieved from: https://www.wsj.com/articles/google-vs-googlehow-nonstop-political-arguments-rule-its-workplace-1525190574

Häusser, J. A., Kattenstroth, M., van Dick, R., \& Mojzisch, A. (2012). "We” are not stressed: Social identity in groups buffers neuroendocrine stress reactions. Journal of Experimental Social Psychology, 48(4), 973-977. https://doi.org/10.1016/j.jesp.2012.02.020

Higgins, E. T., King, G. A., \& Mavin, G. H. (1982). Individual construct accessibility and subjective impressions and recall. Journal of Personality and Social Psychology, 43(1), $35-47$.

Hirst, G., van Dick, R., \& van Knippenberg, D. (2009). A social identity perspective on leadership and employee creativity. Journal of Organizational Behavior, 30(7), 963982. https://doi.org/10.1002/job.600

Hogg, M. A., \& Abrams, D. (1988). Social identifications: A social psychology of intergroup relations and group processes. Routledge.

Hogg, M. A., \& Terry, D. J. (2000). Social identity and self-categorization processes in organizational contexts. Academy of Management Review, 25(1), 121-140.

Hong, Y., Morris, M. W., Chiu, C., \& Benet-Martínez, V. (2000). Multicultural minds: A dynamic constructivist approach to culture and cognition. American Psychologist, 55(7), 709-720. https://doi.org/10.1037/0003-066X.55.7.709

Hornsey, M. J. (2008). Social identity theory and self-categorization theory: A historical review. Social and Personality Psychology Compass, 2(1), 204-222. 


\section{REFRAMING THE SOCIAL/PERSONAL IDENTITY DICHOTOMY}

Hornsey, M., \& Jetten, J. (2004). The individual within the group: Balancing the need to belong with the need to be different. Personality and Social Psychology Review, 8(3), 248-264.

Ibarra, H. (1999). Provisional selves: Experimenting with image and identity in professional adaptation. Administrative Science Quarterly, 44, 764-791.

Ibarra, H., \& Barbulescu, R. (2010). Identity as narrative: Prevalence, effectiveness, and consequences of narrative identity work in macro work role transitions. Academy of Management Review, 35(1), 135-154.

Jetten, J., Haslam, S. A., Cruwys, T., Greenaway, K. H., Haslam, C., \& Steffens, N. K. (2017). Advancing the social identity approach to health and well-being: Progressing the social cure research agenda. European Journal of Social Psychology, 47(7), 789-802. https://doi.org/10.1002/ejsp.2333

Jetten, J., McAuliffe, B. J., Hornsey, M. J., \& Hogg, M. A. (2006). Differentiation between and within groups: The influence of individualist and collectivist group norms. European Journal of Social Psychology, 36(6), 825-843.

Jetten, J., \& Postmes, T. (2006). Introduction: The puzzle of individuality and the group. In T. Postmes \& J. Jetten (Eds.), Individuality and the group: Advances in social identity (pp. 1-10). Sage.

Jetten, J., Postmes, T., \& McAuliffe, B. J. (2002). "We're all individuals": Group norms of individualism and collectivism, levels of identification and identity threat. European Journal of Social Psychology, 32(2), 189-207. https://doi.org/10.1002/ejsp.65

Kanter, R. M. (1977). Men and women of the corporation. Basic Books.

Kreiner, G. E., Hollensbe, E. C., \& Sheep, M. L. (2006). Where is the "me" among the "we"? Identity work and the search for optimal balance. Academy of Management Journal, 49(5), 1031-1057.

Kroger, J., \& Adair, V. (2008). Symbolic meanings of valued personal objects in identity transitions of late adulthood. Identity: An International Journal of Theory and Research, 8(1), 5-24. https://doi.org/10.1080/15283480701787251

Leary, M. R., Kelly, K. M., Cottrell, C. A., \& Schreindorfer, L. S. (2013). Construct validity of the need to belong scale: Mapping the nomological network. Journal of Personality Assessment, 95(6), 610-624. https://doi.org/10.1080/00223891.2013.819511

Lee, E. S., Park, T. Y., \& Koo, B. (2015). Identifying organizational identification as a basis for attitudes and behaviors: A meta-analytic review. Psychological Bulletin, 141(5), 1049-1080. https://doi.org/10.1037/bul0000012

Leigh, A., \& Melwani, S. (2019). \#BlackEmployeesMatter: Mega-threats, identity fusion, and enacting positive deviance in organizations. Academy of Management Review, 44(3), 564-591. https://doi.org/10.5465/amr.2017.0127 


\section{REFRAMING THE SOCIAL/PERSONAL IDENTITY DICHOTOMY}

Leonardelli, G. J., Pickett, C. L., \& Brewer, M. B. (2010). Optimal distinctiveness theory: A framework for social identity, social cognition, and intergroup relations. In M. P. Zanna \& J. M. Olson (Eds.), Advances in experimental social psychology (Vol. 43, pp. 63113). Elsevier. https://doi.org/10.1016/S0065-2601(10)43002-6

Lickel, B., Hamilton, D. L., \& Sherman, S. J. (2001). Elements of a lay theory of groups: Types of groups, relational styles, and the perception of group entitativity. Personality and Social Psychology Review, 5(2), 129-140. https://doi.org/10.1207/S15327957PSPR0502_4

Lincoln, Y. S., \& Guba, E. G. (1985). Naturalistic inquiry. Sage.

Markus, H. R., \& Wurf, E. (1987). The dynamic self-concept: A social psychological perspective. Annual Review of Psychology, 38(1), 299-337. https://doi.org/10.1146/annurev.psych.38.1.299

Mead, G. H. (1934). Mind, self, and society: From the standpoint of a social behaviorist. University of Chicago Press.

Meister, A., Jehn, K. A., \& Thatcher, S. M. B. (2014). Feeling misidentified: The consequences of internal identity asymmetries for individuals at work. Academy of Management Review, 39(4), 488-512. https://doi.org/10.5465/amr.2013.0102

Meyer, J. P., Becker, T. E., \& van Dick, R. (2006). Social identities and commitments at work: Toward an integrative model. Journal of Organizational Behavior, 27(5), 665 683. https://doi.org/10.1002/job.383

Minbashian, A., Beckmann, N., \& Wood, R. E. (2018). Emotional intelligence and individual differences in affective processes underlying task-contingent conscientiousness. Journal of Organizational Behavior, 39(9), 1182-1196. https://doi.org/10.1002/job.2233

Miscenko, D., \& Day, D. V. (2016). Identity and identification at work. Organizational Psychology Review, 6(3), 215-247. https://doi.org/10.1177/2041386615584009

Oakes, P. J. (1987). The salience of social categories. In J. Turner, M. A. Hogg, P. J. Oakes, S. D. Reicher, \& M. S. Wetherell (Eds.), Rediscovering the social group: A selfcategorization theory (pp. 117-141). Basil Blackwell.

Oakes, P., \& Turner, J. C. (1986). Distinctiveness and the salience of social category memberships: Is there an automatic perceptual bias towards novelty? European Journal of Social Psychology, 16(4), 325-344. https://doi.org/10.1002/ejsp.2420160403

Pan, N. D., Gruber, M., \& Binder, J. (2019). Painting with all the colors: The value of social identity theory for understanding social entrepreneurship. Academy of Management Review, 44(1), 213-215. https://doi.org/10.5465/amr.2017.0504

Petriglieri, J. L. (2011). Under threat: Responses to and the consequences of threats to individuals' identities. Academy of Management Review, 36(4), 641-662. https://doi.org/10.5465/amr.2009.0087 


\section{REFRAMING THE SOCIAL/PERSONAL IDENTITY DICHOTOMY}

Pickett, C. L., \& Leonardelli, G. J. (2006). Using collective identities for assimilation and differentiation. In T. Postmes \& J. Jetten (Eds.), Individuality and the group: Advances in social identity (pp. 56-73). Sage.

Piening, E. P., Salge, T. O., Antons, D., \& Kreiner, G. E. (2020). Standing together or falling apart? Understanding employees' responses to organizational identity threats. Academy of Management Review, 45(2), 325-351. https://doi.org/10.5465/amr.2016.0457

Podsakoff, P. M., MacKenzie, S. B., \& Podsakoff, N. P. (2016). Recommendations for creating better concept definitions in the organizational, behavioral, and social sciences. Organizational Research Methods, 19(2), 159-203. https://doi.org/10.1177/1094428115624965

Pratt, M. G., \& Foreman, P. (2000a). Classifying managerial responses to multiple organizational identities. Academy of Management Review, 25(1), 18-42. https://doi.org/10.2307/2695840

Pratt, M. G., \& Foreman, P. O. (2000b). Conclusion: identity dialogues. Academy of Management Review, 25(1), 141-152.

Pratt, M. G., Rockmann, K. W., \& Kaufmann, J. B. (2006). Constructing professional identity: The role of work identity and learning cycles in the customization of identity among medical residents. Academy of Management Journal, 49(2), 235-262.

Proshansky, H. M. (1978). The city and self-identity. Environment and Behavior, 10(2), 147169.

Ramarajan, L. (2014). Past, present and future research on multiple identities: Toward an intrapersonal network approach. Academy of Management Annals, 8(1), 589-659. https://doi.org/10.1080/19416520.2014.912379

Ramarajan, L., Berger, I. E., \& Greenspan, I. (2017). Multiple identity configurations: The benefits of focused enhancement for prosocial behavior. Organization Science, 28(3), 495-513. https://doi.org/10.1287/orsc.2017.1129

Ramarajan, L., \& Reid, E. (2013). Shattering the myth of separate worlds: Negotiating nonwork identities at work. Academy of Management Review, 38(4), 621-644. https://doi.org/10.5465/amr.2011.0314

Reicher, S. D., Spears, R., \& Postmes, T. (1995). A social identity model of deindividuation phenomena. European Review of Social Psychology, 6(1), 161-198. https://doi.org/10.1080/14792779443000049

Reid, A., \& Deaux, K. (1996). Relationship between social and personal identities: Segregation or integration? Journal of Personality and Social Psychology, 71(6), 10841091.

Riketta, M., \& Van Dick, R. (2005). Foci of attachment in organizations: A meta-analytic comparison of the strength and correlates of workgroup versus organizational 


\section{REFRAMING THE SOCIAL/PERSONAL IDENTITY DICHOTOMY}

identification and commitment. Journal of Vocational Behavior, 67(3), 490-510. https://doi.org/10.1016/j.jvb.2004.06.001

Rogers, K. M., Corley, K. G., \& Ashforth, B. E. (2017). Seeing more than orange: Organizational respect and positive identity transformation in a prison context. Administrative Science Quarterly, 62(2), 219-269. https://doi.org/10.1177/0001839216678842

Rothbard, N. P., \& Ramarajan, L. (2009). Checking your identities at the door? Positive relationships between nonwork and work identities. In L. M. Roberts \& J. E. Dutton (Eds.), Exploring positive identities and organizations (pp. 127-144). Routledge.

Simon, B. (1997). Self and group in modern society: Ten theses on the individual self and collective self. In R. Spears, P. J. Oakes, N. Ellemers, \& S. A. Haslam (Eds.), The social psychology of stereotyping and group life (pp. 318-335). Blackwell.

Simon, B., Pantaleo, G., \& Mummendey, A. (1995). Unique individual or interchangeable group member? The accentuation of intragroup differences versus similarities as an indicator of the individual self versus the collective self. Journal of Personality and Social Psychology, 69(1), 106-119. https://doi.org/10.1037/0022-3514.69.1.106

Sluss, D. M., \& Ashforth, B. E. (2007). Relational identity and identification: Defining ourselves through work relationships. Academy of Management Review, 32(1), 9-32.

Sluss, D. M., \& Ashforth, B. E. (2008). How relational and organizational identification converge: Processes and conditions. Organization Science, 19(6), 807-823. https://doi.org/10.1287/orsc.1070.0349

Snyder, C. R., \& Fromkin, H. L. (1977). Abnormality as a positive characteristic: The development and validation of a scale measuring need for uniqueness. Journal of Abnormal Psychology, 86(5), 518-527. https://doi.org/10.1037/0021-843X.86.5.518

Steffens, N. K., Haslam, S. A., Schuh, S. C., Jetten, J., \& van Dick, R. (2017). A metaanalytic review of social identification and health in organizational contexts. Personality and Social Psychology Review, 21(4), 303-335. https://doi.org/10.1177/1088868316656701

Stryker, S. (2007). Identity theory and personality theory: Mutual relevance. Journal of Personality, 75(6), 1083-1102. https://doi.org/10.1111/j.1467-6494.2007.00468.x

Summers, J. K., Howe, M., McElroy, J. C., Ronald Buckley, M., Pahng, P., \& Cortes-Mejia, S. (2018). A typology of stigma within organizations: Access and treatment effects. Journal of Organizational Behavior, 39(7), 853-868. https://doi.org/10.1002/job.2279

Swann Jr, W. B., Gomez, A., Seyle, D. C., Morales, J. F., \& Huici, C. (2009). Identity fusion: The interplay of personal and social identities in extreme group behavior. Journal of Personality and Social Psychology, 96(5), 995-1011. https://doi.org/10.1037/a0013668 


\section{REFRAMING THE SOCIAL/PERSONAL IDENTITY DICHOTOMY}

Tajfel, H. (1970). Experiments in intergroup discrimination. Scientific American, 233(5), 96102.

Tajfel, H. (1974). Social identity and intergroup behaviour. Social Science Information, 13(2), 65-93. https://doi.org/10.1177/053901847401300204

Tajfel, H. (1978). Interindividual and intergroup behaviour. In H. Tajfel (Ed.), Differentiation between social groups (pp. 27-60). Academic Press.

Tajfel, H., Billig, M. G., Bundy, R. P., \& Flament, C. (1971). Social categorization and intergroup behaviour. European Journal of Social Psychology, 1(2), 149-178. https://doi.org/10.1002/ejsp.2420010202

Tajfel, H., \& Turner, J. (1979). An integrative theory of intergroup conflict. In W. G. Austin $\&$ S. Worchel (Eds.), The social psychology of intergroup relations (pp. 33-47). Monterey: Brooks/Cole.

Thoits, P. A., \& Virshup, L. K. (1997). Me's and we's: Forms and functions of social identities. In R. D. Ashmore \& L. Jussim (Eds.), Self and identity: Fundamental issues (pp. 106-134). Oxford University Press.

Trafimow, D., Triandis, H. C., \& Goto, S. G. (1991). Some tests of the distinction between the private self and the collective self. Journal of Personality and Social Psychology, 60(5), 649-655. https://doi.org/10.1037/0022-3514.60.5.649

Turner, J.C. (1982). Towards a cognitive redefinition of the social group. In H. Taijfel (Ed.), Social identity and intergroup relations (pp. 15-40). Cambridge University Press.

Turner, J. C. (1985). Social categorization and the self-concept: A social cognitive theory of group behavior. In E. J. Lawler (Ed.), Advances in group processes: A research annual (pp. 77-121). JAI Press.

Turner, J.C., Hogg, M. A., Oakes, P. J., Reicher, S. D., \& Wetherell, M. S. (1987). Rediscovering the social group: A self-categorization theory. Basil Blackwell.

Turner, J. C., Oakes, P. J., Haslam, S. A., \& McGarty, C. (1994). Self and collective: Cognition and social context. Personality and Social Psychology Bulletin, 20(5), 454 463. https://doi.org/10.1177/0146167294205002

Turner, J. C., \& Reynolds, K. J. (2012). Self-categorization theory. In P. A. M. Van Lange, A. W. Kruglanski, \& E. T. Higgins (Eds.), Handbook of theories of social psychology (pp. 455-459). Sage. https://doi.org/10.1016/B978-0-08-097086-8.24087-7

Turner, J. C., Reynolds, K. J., Haslam, S. A., \& Veenstra, K. E. (2006). Reconceptualizing personality: Producing individuality by defining the personal self. In T. Postmes \& J. Jetten (Eds.), Individuality and the group: Advances in social identity (pp. 11-36). Sage.

Van Der Vegt, G. S., \& Bunderson, S. J. (2005). Learning and performance in multidisciplinary teams: The importance of collective team identification. Academy of Management Journal, 48(3), 532-547. 


\section{REFRAMING THE SOCIAL/PERSONAL IDENTITY DICHOTOMY}

van Dick, R., Grojean, M. W., Christ, O., \& Wieseke, J. (2006). Identity and the extra mile: Relationships between organizational identification and organizational citizenship behaviour. British Journal of Management, 17, 283-301. https://doi.org/10.1111/j.14678551.2006.00520.x

van Dick, R., Hirst, G., Grojean, M. W., \& Wieseke, J. (2007). Relationships between leader and follower organizational identification and implications for follower attitudes and behaviour. Journal of Occupational and Organizational Psychology, 80, 133-150. https://doi.org/10.1348/096317905X71831

van Dick, R., Wagner, U., Stellmacher, J., \& Christ, O. (2005). Category salience and organizational identification. Journal of Occupational and Organizational Psychology, 78(2), 273-285. https://doi.org/10.1348/096317905X25779

van Knippenberg, D. (2000). Work motivation and performance: A social identity perspective. Applied Psychology: An International Review, 49(3), 357-371.

Vignoles, V. L. (2009). The motive for distinctiveness: A universal, but flexible human need. In S. J. Lopez \& C. R. Snyder (Eds.), The Oxford handbook of positive psychology (2nd ed., pp. 491-500). Oxford: Oxford. https://doi.org/10.1093/oxfordhb/9780195187243.013.0047

Vignoles, V. L. (2011). Identity motives. In S. J. Schwartz, K. Luyckz, \& V. L. Vignoles (Eds.), Handbook of identity theory and research (pp. 403-432). Springer. https://doi.org/10.1007/978-1-4419-7988-9_18

Vignoles, V. L. (2019). Identity: Personal and social. In K. Deaux \& M. Snyder (Eds.), Oxford handbook of personality and social psychology (2nd ed., pp. 289-316). Oxford University Press.

Vough, H. (2012). Not all identifications are created equal: Exploring employee accounts for workgroup, organizational, and professional identification. Organization Science, 23(3), 778-800. https://doi.org/10.1287/orsc.1110.0654

Vough, H. C., Bataille, C. D., Noh, S. C., \& Lee, M. D. (2015). Going off script: How managers make sense of the ending of their careers. Journal of Management Studies, 52(3), 414-440. https://doi.org/10.1111/joms.12126

Walker, B.W., \& Bridgman, T. (2013). Organisational identity and alcohol use among young employees: A case study of a professional services firm. International Journal of Drug Policy, 24(6), 597-604. https://doi.org/10.1016/j.drugpo.2013.07.005

Walker, B. W., \& Caprar, D. V. (2020). When performance gets personal: Towards a theory of performance-based identity. Human Relations. 73(8), 1077-1105.

Zhu, L., Martens, J. P., \& Aquino, K. (2012). Third party responses to justice failure. Organizational Psychology Review, 2(2), 129-151.

https://doi.org/10.1177/2041386611434655 
REFRAMING THE SOCIAL/PERSONAL IDENTITY DICHOTOMY

\section{Table 1}

The Social/Personal Identity Dichotomy in Academy of Management Review Articles, 19892020

\begin{tabular}{|c|c|}
\hline Citation & Relevant Excerpt from Article \\
\hline $\begin{array}{l}\text { Ashforth } \\
\text { and Mael } \\
(1989)\end{array}$ & $\begin{array}{l}\text { "According to SIT [social identity theory], the self-concept is comprised of a } \\
\text { personal identity encompassing idiosyncratic characteristics (e.g., bodily } \\
\text { attributes, abilities, psychological traits, interests) and a social identity } \\
\text { encompassing salient group classifications." (p. 21) }\end{array}$ \\
\hline $\begin{array}{l}\text { Ashforth } \\
\text { and } \\
\text { Humphrey } \\
\text { (1993) }\end{array}$ & $\begin{array}{l}\text { "According to social identity theory, the self-concept is comprised of a } \\
\text { personal identity encompassing idiosyncratic characteristics (e.g., traits, } \\
\text { abilities) and a social identity encompassing salient group classifications } \\
\text { (e.g., religious affiliation, organizational role) (Ashforth \& Mael, 1989; } \\
\text { Tajfel \& Turner, 1985)." (p. 98) }\end{array}$ \\
\hline $\begin{array}{l}\text { Brown } \\
\text { (1997) }\end{array}$ & $\begin{array}{l}\text { "[The self-concept] consists of two subcomponents: (1) personal identity, } \\
\text { which refers to person-specific attributes, and (2) social identity, which } \\
\text { refers to social group memberships." (p. 650) }\end{array}$ \\
\hline $\begin{array}{l}\text { Ashforth } \\
\text { and Kreiner } \\
\text { (1999) }\end{array}$ & $\begin{array}{l}\text { "According to social identity theory, self-definitions are an amalgam of the } \\
\text { idiosyncratic attributes (e.g., assertive, ambitious) and social identities (e.g., } \\
\text { gender, occupation) that are most relevant (Tajfel \& Turner, 1986)." (p. 417) }\end{array}$ \\
\hline $\begin{array}{l}\text { Pratt and } \\
\text { Foreman } \\
(2000 a)\end{array}$ & $\begin{array}{l}\text { "... as evident in social identity theory, an individual's self-concept can have } \\
\text { both personal and social identities. Here, social identities reside in an } \\
\text { individual (claimant), but the identity may capture values and beliefs } \\
\text { belonging to a social group (target)." (p. 142) }\end{array}$ \\
\hline $\begin{array}{l}\text { Pratt and } \\
\text { Foreman } \\
(2000 \mathrm{~b})\end{array}$ & $\begin{array}{l}\text { "We have noted that organizational identities are properties of a collective. } \\
\text { Individual identities, in contrast, can be either social or idiosyncratic to the } \\
\text { individual (cf. Tajfel, 1981; Tajfel \& Turner, 1979)." (p. 35) }\end{array}$ \\
\hline $\begin{array}{l}\text { Brickson } \\
(2000)\end{array}$ & $\begin{array}{l}\text { "At the crux of social identity theory - the other main intergroup relations } \\
\text { theory that has informed organizational diversity interventions - is the notion } \\
\text { that individuals' identities contain both personal and social identity } \\
\text { components, where social identities are viewed as collective in nature." (p. } \\
\text { 83) }\end{array}$ \\
\hline $\begin{array}{l}\text { Ellemers, } \\
\text { De Gilder, } \\
\text { \& Haslam } \\
(2004)\end{array}$ & $\begin{array}{l}\text { "The central assumption underlying social identity theory (Tajfel, 1974, } \\
\text { 1975, 1978) is that while in some social situations people think of } \\
\text { themselves as independent individuals who interact with each other on the } \\
\text { basis of personal characteristics or preferences (e.g., in friendship groups), } \\
\text { there are many social settings in which people primarily think of themselves } \\
\text { and others in terms of particular group memberships (e.g., in terms of their } \\
\text { professional roles)." (p. 461) }\end{array}$ \\
\hline $\begin{array}{l}\text { Sluss and } \\
\text { Ashforth } \\
(2007)\end{array}$ & $\begin{array}{l}\text { "What has been missing, though, is a specific focus on how one's definition } \\
\text { of self might be influenced by interpersonal relationships and the consequent } \\
\text { interplay of three "levels" of identity: individual (or personal), interpersonal, } \\
\text { and collective (or group, social)." (p. 9) }\end{array}$ \\
\hline $\begin{array}{l}\text { Cooper and } \\
\text { Thatcher } \\
(2010)\end{array}$ & $\begin{array}{l}\text { "Self-concepts represent knowledge structures that consist of beliefs about } \\
\text { the self, including one's attributes, social roles, and goals (Fiske \& Taylor, } \\
\text { 1991). The individual, relational, and collective self-concepts refer to } \\
\text { whether the self is viewed as separate from others, linked to others through } \\
\text { relationships, or included in large groups, respectively (Brewer \& Chen, } \\
\text { 2007; Gelfand, Smith, Raver, \& Nishii, 2006; Kuhnen \& Oyserman, 2002; }\end{array}$ \\
\hline
\end{tabular}




\begin{tabular}{|c|c|}
\hline & $\begin{array}{l}\text { Lord, Brown, \& Freiberg, 1999). Individuals have all three self-concepts- } \\
\text { individual, relational, and collective- but differ in the importance they place } \\
\text { on each aspect of the self (Brewer \& Chen, 2007).” (p. 519) }\end{array}$ \\
\hline $\begin{array}{l}\text { Ibarra and } \\
\text { Barbulescu } \\
(2010)\end{array}$ & $\begin{array}{l}\text { "Identities are the various meanings attached to an individual by the self and } \\
\text { by others; these meanings may be based on the social roles a person holds- } \\
\text { social identities-or on personal, idiosyncratic characteristics the individual } \\
\text { displays and others attribute to him or her based on his or her conduct- } \\
\text { personal identities." (p. 137) }\end{array}$ \\
\hline $\begin{array}{l}\text { Petriglieri } \\
\text { (2011) }\end{array}$ & $\begin{array}{l}\text { "To define identity at the individual level, I draw from and combine the two } \\
\text { established theoretical perspectives on individual identity in organization } \\
\text { studies: social identity theory (Tajfel \& Turner, 1986) and identity theory } \\
\text { (Stryker, 1987; Stryker \& Burke, 2000). These hold that an individual's } \\
\text { identities are based on group membership and roles (referred to collectively } \\
\text { here as social identities) and on unique characteristics and traits (referred to } \\
\text { here as personal identities; Ashforth, 2001)." (p. 644) }\end{array}$ \\
\hline $\begin{array}{l}\text { Meister, } \\
\text { Jehn, and } \\
\text { Thatcher } \\
\text { (2014) }\end{array}$ & $\begin{array}{l}\text { “...an individual may define herself using personal identities based on } \\
\text { attributes, traits, or competencies (e.g., smart, conscientious; Polzer et al., } \\
\text { 2002), interpersonal or societal roles (e.g., parent, wife; Stryker \& Burke, } \\
\text { 2000; Stryker \& Serpe, 1982), social categories or group memberships (e.g., } \\
\text { gender, ethnicity; Hogg, 1996; Tajfel, 1982; Turner, 1987), or organizational } \\
\text { or professional memberships (e.g., physician, board member; Kreiner, } \\
\text { Hollensbe, \& Sheep, 2006; Pratt, Rockmann, \& Kaufmann, 2006).” (p. 490) }\end{array}$ \\
\hline $\begin{array}{l}\text { Ashforth, } \\
\text { Schinoff, } \\
\text { and Rogers } \\
(2016)\end{array}$ & $\begin{array}{l}\text { "A social identity refers to attributes that reflect group membership, while a } \\
\text { personal identity refers to idiosyncratic attributes that distinguish an } \\
\text { individual from others." (p. 31) }\end{array}$ \\
\hline $\begin{array}{l}\text { Bolinger, } \\
\text { Klotz, and } \\
\text { Leavitt } \\
(2018)\end{array}$ & $\begin{array}{l}\text { "Self-categorization approaches to workplace identification posit that } \\
\text { individuals tend to think of themselves across three distinct levels of identity, } \\
\text { focusing on their individual attributes (i.e., personal identity), their role- } \\
\text { based relationships vis-a-vis relational others (i.e., relational identity), or } \\
\text { their membership and standing within a larger collective or group (i.e., } \\
\text { collective identity; Brewer \& Gardner, 1996; Cooper \& Thatcher, 2010)." (p. } \\
\text { 686) }\end{array}$ \\
\hline $\begin{array}{l}\text { Leigh and } \\
\text { Melwani } \\
\text { (2019) }\end{array}$ & $\begin{array}{l}\text { "Individuals in organizations have multiple identities (Ramarajan, 2014), } \\
\text { including personal identities, or idiosyncratic characteristics of an individual; } \\
\text { social identities, or aspects of an individual's self-concept that are derived } \\
\text { from membership in social groups (e.g., race or gender); and organizational } \\
\text { identities, which include the self-definitions that arise from workgroups or } \\
\text { roles within organizations (Ashforth \& Mael, 1989; Tajfel \& Turner, 1985)." } \\
\text { (p. 569) }\end{array}$ \\
\hline $\begin{array}{l}\text { Pan, } \\
\text { Gruber, and } \\
\text { Binder } \\
(2019)\end{array}$ & $\begin{array}{l}\text { "Personal identity relates to individual, intrapersonal behavior (shaped by } \\
\text { idiosyncratic individual attributes); social identity captures social, } \\
\text { interpersonal behavior (driven by identification with a collective); and role } \\
\text { identity, focused on an individual's role-based relationships, combines } \\
\text { elements of the intrapersonal and the interpersonal (Tajfel, 1982; Terry, } \\
\text { Hogg, \& White, 1999)." (p. 213) }\end{array}$ \\
\hline
\end{tabular}




\begin{tabular}{|l|l|}
\hline & $\begin{array}{l}\text { "...we also argue that anthropomorphism enables individuals to readily } \\
\text { recognize three levels of a human-like OI [organizational identity] analogous } \\
\text { to the three levels of a person's identity. Following Brewer and Gardner }\end{array}$ \\
$\begin{array}{l}\text { Ashforth, } \\
\text { Schinoff, } \\
\text { and } \\
\text { Brickson } \\
\text { (2020) }\end{array}$ & $\begin{array}{l}\text { Thatcher, 2010), the latter includes a social, relational, and individual level. } \\
\text { The social level captures the person as a prototypical member of a group } \\
\text { (e.g., "I'm a member of Nike"), the relational (or interpersonal) level } \\
\text { captures the person's role-related relationships (e.g., "I'm a coworker of } \\
\text { Helen"), and the individual (or personal) level captures the person as unique } \\
\text { (e.g., "I'm stubborn")." (p. 34) }\end{array}$ \\
\hline $\begin{array}{l}\text { Piening, } \\
\text { Salge, } \\
\text { Antons, and } \\
\text { Kreiner } \\
\text { (2020) }\end{array}$ & $\begin{array}{l}\text { "Three self-concept levels or "loci of self-definition" (Brickson, 2000: 84) } \\
\text { can be distinguished: personal, relational, and collective. First, people define } \\
\text { themselves in terms of their personal attributes (e.g., personality, abilities, } \\
\text { interests). At this individual level, one's sense of uniqueness and self-esteem } \\
\text { is based on favorable comparisons with other people in a given social context } \\
\text { (Johnson et al., 2006). Second, the relational level involves self-definition } \\
\text { based on connections and role relationships with others, with one's self- } \\
\text { worth being influenced by the quality of these relationships (Brewer \& } \\
\text { Gardner, 1996). Third, the collective level refers to defining oneself in terms } \\
\text { of the social groups (e.g., gender, ethnic groups, professions, or } \\
\text { organizations) one belongs to. Accordingly, one's sense of self is tied to the } \\
\text { social standing and outcomes of these groups as a whole (Brewer, 1991). } \\
\text { While an individual's self-concept contains all three of these levels, their } \\
\text { relative importance (or "identity orientation") varies from individual to } \\
\text { individual depending on personal and situational factors (Brickson, 2000; } \\
\text { Cooper \& Thatcher, 2010)." (p. 327) }\end{array}$ \\
\hline
\end{tabular}




\section{REFRAMING THE SOCIAL/PERSONAL IDENTITY DICHOTOMY}

\section{Figure 1}

A two-dimensional vs. unidimensional approach to the social and personal experience of identity

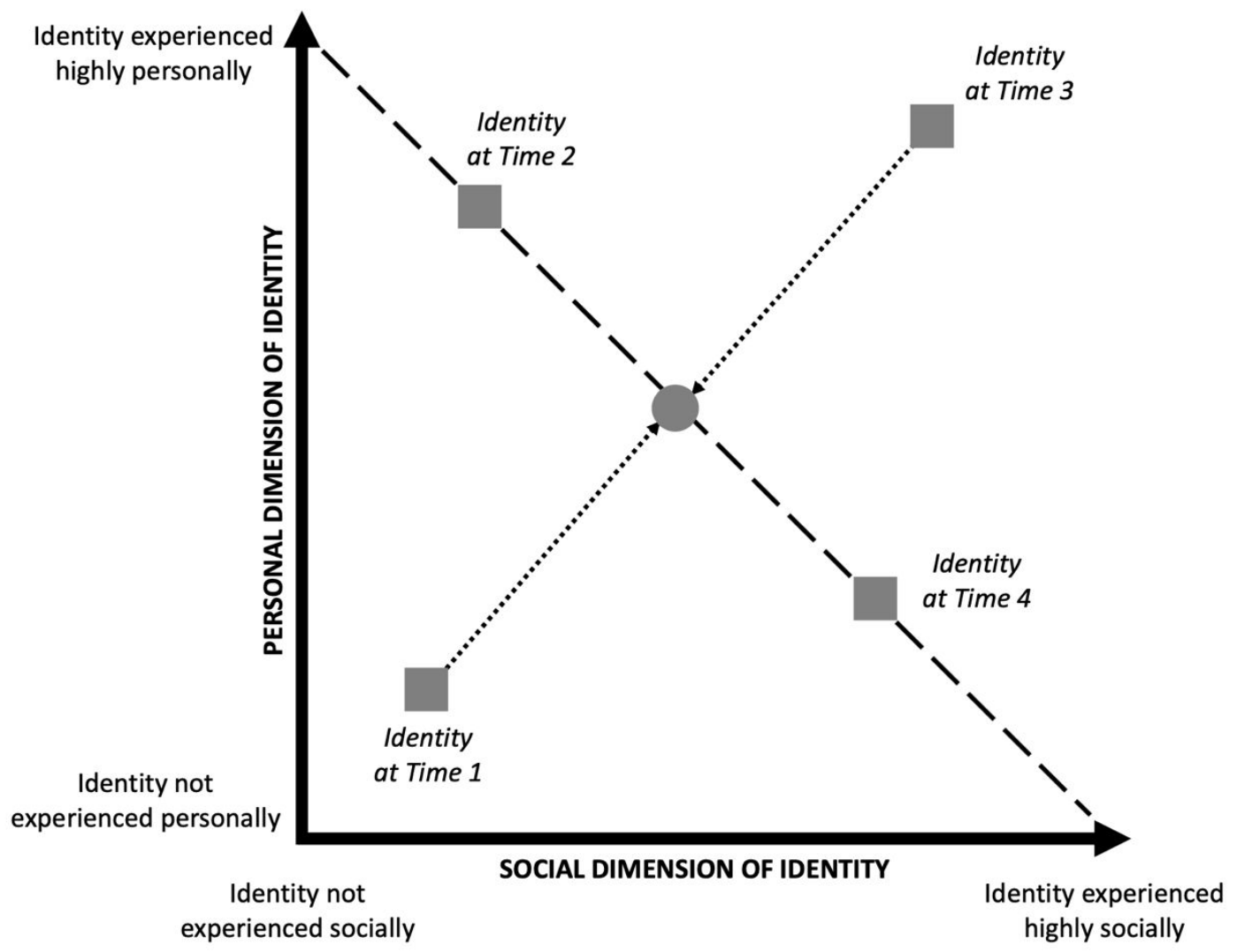

Note. The circular marker indicates where the experience of the identity at times 1 and 3 would be reported under a unidimensional (rather than two-dimensional) approach. The dotted black line indicates the artificial transposition (i.e., distortion of meaning) that would take place as a result of this. 


\section{REFRAMING THE SOCIAL/PERSONAL IDENTITY DICHOTOMY}

\section{Figure 2}

Four forms of variation along the social and personal dimensions of identity

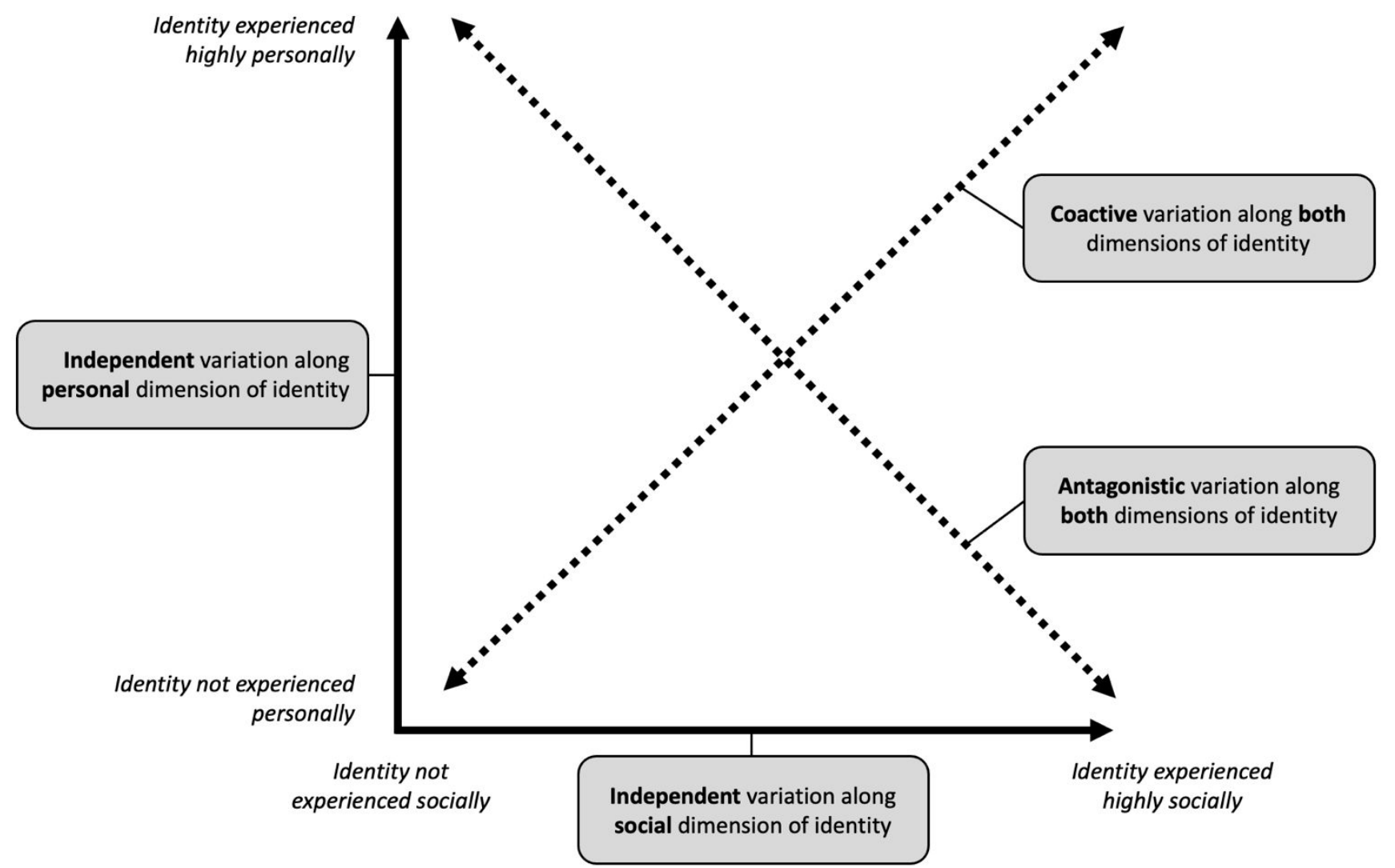

